\title{
EGZEGEZA KSIĘGI IZAJASZA 61,1-11: HISTORIA REDAKCJI I PYTANIE O TOŻSAMOŚĆ PROROKA ZWANEGO TRITOIZAJASZEM
}

\begin{abstract}
Wprowadzenie
Począwszy od przełomowego komentarza Bernharda Duhm z 1982 r., Księgę Izajasza dzieli się na trzy części: Protoizajasza (rozdz. 1-39), Deuteroizajsza (40-55) i Tritoizajsza (56-66), które powstały w różnych czasach, odpowiednio przedwygnaniowych, wygnaniowych i powygnaniowych. Ostatnia z tych części zajmuje się sytuacją w powygnaniowej Jerozolimie czy Judei. Od dawna również dostrzegano, że Deuteroizajasz i Tritoizajasz są spokrewnieni nie tylko tematycznie, ale i językowo, z czego Karl Elliger wysnuł wniosek, że Tritoizajasz (Triz) był uczniem Deuteroizajsza (Dtiz). ${ }^{1}$ Jednak intensywne badania z zakresu historii redakcji tak Triz (Klaus Koenen, ${ }^{2}$ Odil Hannes Steck, ${ }^{3}$ Wofgang Lau ${ }^{4}$ ), jak i Dtiz (przede
\end{abstract}

1 K. E 11 i g e r, Deuterojesaja in seinem Verhältnis zu Tritojesaja, BWANT 63, Stuttgart 1933. Tak jeszcze W.H. S c h m i d t, Wprowadzenie do Starego Testamentu, tłum. P. M a th ä u s, Bielsko-Biała 1997, s. 225.

2 K. K o e n e n, Ethik und Eschatologie im Tritojesajabuch: Eine literarkritische und redaktionsgeschichtliche Studie, WMANT 62, Neukirchen-Vluyn 1990.

3 O.-H. S t e c k, Studien zu Tritojesaja, BZAW 203, Berlin-New York 1991.

4 W. L a u, Schriftgelehrte Prophetie in Jes 56-66: Eine Untersuchung zu den literarischen Bezugen in den letzten elf Kapiteln des Jesajabuches, BZAW 225, Berlin-New York 1994. 
wszystkim Reinhard Gregor Kratz ${ }^{5}$ i Jürgen van Oorschot ${ }^{6}$ ) doprowadziły do zmiany w postrzeganiu trzeciej części Księgi Izajasza, gdzie mamy do czynienia ze schriftgelehrte Prophetie, profetyzmem uczonym w Piśmie, który nie ma zakorzenienia w ustnym zwiastowaniu proroka, a bazuje na wcześniejszych przekazach.

O ile W. Lau mówił o uczonym w Piśmie proroku, o osobowości prorockiej, to O.H. Steck przekonuje, że mamy do czynienia nie z prorokiem podobnym do postaci takich jak Amos, Izajasza, Micheasz czy Jeremiasz, a nawet anonimowy Deuteroizajasz, lecz z kręgiem tradentów (przekazicieli tradycji), którzy w rzeczywistości byli redaktorami Księgi Deuteroizajasza, a na późniejszych etapach całości Księgi Izajasza. ${ }^{7}$ Takie postrzeganie tekstów z Iz 56-66 opierają się na obserwacji, że na rozdziały te składają się większe kompozycje literackie, za którymi nie stoją małe jednostki, oraz szerokie, nieraz dosłowne, czerpanie z wcześniejszych rozdziałów Dtiz czy też całej Księgi Izajasza. W przypadku Dtiz jeszcze tak miało nie być, ${ }^{8}$ choć i tam coraz częściej mowa jest raczej o kompozycjach, z których coraz trudniej wydobyć zwiastowanie

5 G. K ratz, Kyros im Deuterojesaja-Buch. Redaktionsgeschichtliche Untersuchungen zu Entstehung und Theologie von Jes 40-55, FAT 1, Tübingen 1991.

6 J. v a n O o r s h ot, Von Babel zum Zion: Eine literarkritische und redaktionsgeschichtliche Untersuchung, BZAW 206, Berlin-New York 1993.

7 Zob. zwł. O.-H. S t e c k, Anschlußprobleme einer redaktionellen Entstehung von Tritojesaja, w: t e n ż e, Studien zu Tritojesaja, s. 270-275.

8 Wystarczy spojrzeć do komentarzy takich jak: K. E 11 i g e r, Deuterojesaja, t. 1: Jesaja 40,1-45,7, BK XI/1, Neukirchen-Vluyn 1989²; H.-J. H e r m i s s o n, Deuterojesaja, t. 2: Jesaja 45,8-49,13, BK XI/2, Neukirchen-Vluyn 2003; t e n ż e, Deuterojesaja, t. 3: Jesaja 49,14-55,13, BK XI/3, Neukirchen-Vluyn 2017; J.L. K o o l e, Isaiah III, t. 1: Isaiah 40-48, HCOT, Kampen 1997; t e n ż e, Isaiah III, t. 2: Isaiah 49-55, HCOT, Kampen 1998. Tak samo O.-H. S t e c k, Anschlußprobleme einer redaktionellen Entstehung von Tritojesaja, s. 271 przyp. 5. 
domniemanego proroka. ${ }^{9}$ O.H. Steck ${ }^{10}$ twierdził zatem, że nie da się odnaleźć „małych jednostek tekstowych” w Triz. W. Lau jednak odnajduje mniej lub bardziej „relatywnie samodzielne fragmenty”, jednostki tematyczne (najmocniej ma to dotyczyć rozdz. 61), ${ }^{11}$ ale i tak jedynie w postaci większych kompozycji, dla których charakterystyczne jest korzystanie i cytowanie wcześniejszych tekstów, przede wszystkim Dtiz.

Jeśli teza o tym, że w rzeczywistości począwszy od Triz nie mamy do czynienia z typowym profetyzmem, którego istotą było zwiastowanie słowa JHWH, a z pisemnym przekazywaniem i aktualizowaniem w postaci intensywnej pracy literackiej, ${ }^{12}$ miałaby być krytycznie zweryfikowana, to trzeba zwrócić się ku Iz 60-62, co do których panuje zasadniczy konsens wśród badaczy, że tworzą ono jądro przekazów Tritoizajaszowych, ${ }^{13}$ wokół którego zgroma-

9 W egzegezie Starego Testamentu od lat 80. XX w. doszło do pewnej przemiany paradygmatu badawczego: punkt ciężkości przesunął się z poszukiwania (pierwotnych) małych jednostek tekstowych na badanie dużych kompozycji obejmujących nieraz całe księgi - zob. w odniesieniu do Dtiz komentarze: K. B a 1 t z e r, Deutero-Jesaja, KAT X,2, Gütersloh 1999; U. B e r g e s, Jesaja 40-48, HThK.AT, Freiburg-Basel-Wien 2008; t e n ż e, Jesaja 49-55, HThK.AT, Freiburg-Basel-Wien 2015; a np. w odniesieniu do psalmów F.-L. H o s s fe ld, E. Z e n g e r, Psalmen 51-100, HThK.AT, Freiburg-Basel-Wien 200033; c i ż, Psalmen 101-150, HThK.AT, Freiburg-Basel-Wien 2008.

10 O.-H. S t e c k, Anschlußprobleme einer redaktionellen Entstehung von Tritojesaja, s. 271; też J. B 1 e n k i n s o p p, Isaiah 56-66: A New Translation with Introduction and Commentary, AnB 19, New Haven-London 2003, s. 41.

11 Tak W. L a u, Schriftgelehrte Prophetie in Jes 56-66, s. 89.

12 Zob. tamże, s. 320-321.

13 W.H. S c h m i d t, Wprowadzenie do Starego Testamentu, s. 224; H.-W. J ü n $\mathrm{g} l$ i n g, Das Buch Jesaja, w: E. Z e n g e r i in., Einleitung in das Alte Testament, Kohlhammer Studienbücher Theologie 1,1, Stuttgart 20087, s. 437, 444; C. W e s t e r m a n n, Das Buch Jesaja: Kapitel 40-66, ATD 19, Göttingen-Zürich 1986, s. 280; O.-H. S t e c k, Die redaktionsgeschichtliche Hypothese zu Tritojesaja im Umri $\beta$, w: t e n ż e, Studien zu Tritojesaja, s. 14; W. L a u, Schriftgelehrte Prophetie in Jes 56-66, s. 19-20; J. B 1 e n k i n s o p p, Isaiah 56-66, s. 206; J. G o 1 d i n g a y, A Critical and Exegetical Commentary on Isaiah 56-66, ICC, London-New Dehli-New York-Sydney 2014, s. 6 i in. Na ten konsens powołują się również dwa ostatnie 
dzony został (koncentrycznie) młodszy materiał redakcyjny. ${ }^{14} \mathrm{Co}$ więcej, centralne miejsce zdaje się w nich zajmować rozdz. $61,{ }^{15}$ choć jego relacje z otaczającymi go rozdziałami są już bardzo różnie postrzegane. ${ }^{16}$

W niniejszym artykule poddano analizie centralną perykopę Tritoizajasza, tj. Iz 61, by sprawdzić, na ile możliwe jest zweryfikowanie tych wielu hipotez dotyczących genezy ostatniej części Księgi Izajasza oraz osoby domniemanego proroka. Czy można z niej wysnuć jakieś wnioski dotyczące początków Iz 56-66, tożsamości ewentualnego proroka i jego samopostrzegania. $Z$ wyjątkiem w. 7 przekaz tekstowy nie budzi większych wątpliwości, a trudności gramatyczne i problemy interpretacyjne, które nie zostały poruszone w uwagach do tłumaczenia, będą przedmiotem zainteresowania $\mathrm{w}$ poniższym komentarzu.

opracowania: S. L a b o u v i e, Gottesknecht und neuer David: Der Heilsmittler für Zion und seine Frohbotschaft nach Jesaja 60-62, Forschung zur Bibel 129, Echter, Würzburg 2013; A. S p a n, Die Stadtfrau Zion im Zentrum der Welt: Exegese und Theologie von Jes 60-62, Bonner Biblische Beiträge 175, Bonn University Press / V\&R Unipress, Göttingen 2015.

14 H.-W. J ü n g l i n g, Das Buch Jesaja, s. 438; podobnie W.H. S c h m i d t, Wprowadzenie do Starego Testamentu, s. 224-225; J. Gold in g a y, A Critical and Exegetical Commentary on Isaiah 56-66, s. 5.

15 H.-W. J ü n g 1 i n g, Das Buch Jesaja, s. 438; J. B 1 e n k i n s o p p, Isaiah 56-66, s. 206.

16 Np. W. L a u, Schriftgelehrte Prophetie in Jes 56-66, s. 89, 117, uważa go za odrębną jednostkę, ale pochodzącą od tego samo autora co Iz 60 i 62 i umieszczoną przez niego w środku tej kompozycji; O.-H. S t e c k, Zu jüngsten Untersuchungen von Jes 60-62, w: t e n ż e, Studien zu Tritojesaja, s. 119-139, łączy w jedną całość Iz 60* i 61*, a w Iz 62 odnajduje trzy późniejsze warstwy redakcyjne; J. B 1 e n k i n s o p p, Isaiah 56-66, s. 208-210, wyróżnia rozdz. 61, ale ostatecznie uznaje, że Iz 60-62 zbudowane są ze zróżnicowanego materiału, ale trudno powiedzieć, czy kompilacja ta jest wynikiem działania wielu autorów. Warto zauważyć, że już B. D u h m, Das Buch Jesaja, HKAT 3,1, Göttingen 1982³ , s. 423-424, odnajdywał w nim początek czy środek pisma Tritoizajaszowego, zawierający program prorocki. 


\section{Tłumaczenie i problemy tekstowe Iz 61,1-11}

1 Duch Pana,${ }^{17}$ JHWH jest na mnie, ponieważ namaścił JHWH mnie, abym zwiastowa $1^{18}$ uciśnionym (poniżonym); posłał mnie, abym opatrzy1 ${ }^{19}$ rozbitych wewnętrznie, ${ }^{20}$ abym ogłosił jeńcom wyzwolenie i więźniom uwolnienie, ${ }^{21}$

2 abym ogłosił rok przychylności JHWH i dzień zemsty Boga naszego, aby $(m)^{22}$ pocieszył wszystkich żałobników,

17 W. L a u, Schriftgelehrte Prophetie in Jes 56-66, s. 67 przyp. 201, uważa słowo אִדני za wtórne, gdyż brak go w istotnych świadectwach $\left(Q^{\mathrm{a}}, \mathrm{V}\right.$ czy G, gdzie stoi tylko pojedyncze кúpıoৎ) i nigdy więcej w Biblii Hebrajskiej nie ma sformułowania „duch Pana JHWH”. Ponieważ jednak słowo to pełni funkcję kompozycyjną (por. w.11 i poniżej), trudno byłoby jego wykreślenie uznać za przekonujące.

18 Choć konstrukcja z inf. cs. nie jest całkowicie jednoznaczna (kto jest podmiotem zwiastowania?), to ciąg dalszy wskazuje, że mowa jest o zadaniu posłańca.

19 „Wiązać, zawiązać”, a odnośnie do rany „opatrywać”; zob. W. G e s e n i u s, Hebräisches und Aramäisches Handwörterbuch über das Alte Testament, Springer, Heidelberg-Dordrecht-London-New York $2013^{18}$ (dalej: HAHAT).

20 Dosł. „mających złamane serce”; zob. tamże.

${ }^{21}$ Hapaxl., wywodzący się od czasownika w Iz 42,20 o uszach, który w Q ${ }^{\mathrm{a}}$ i kilku Mss został zapisany bez linii makkef. Może być sztucznym zapisem wyrazu oznaczającego „otwarcie” czy „wypuszczenie na wolność" (zob. HAHAT). Wersję bez linii makkef zaleca też Biblia Herbraica Stuttgartensia, Deutsche Bibelgesellschaft, Stuttgart $1997^{5}$ (dalej: BHS) (lub inf. abs. czasownika), jako że forma ta opiera się na reduplikacji lub dittografii części rdzenia (jak wyjaśnia J.L. K o o l e, Isaiah III, t. 3: Isaiah 56-66, HCOT, Kampen 2001, s. 272; tak też J. B l e n k i n s o p p, Isaiah 56-66, s. 219).

22 Ponownie nie jest jasne, kto jest podmiotem kolejnych inf. O ile wcześniejsze głoszenie było z pewnością zadaniem posłańca, to od w.2b podmiotem mógłby być Bóg (o którym mowa w w.2a). Dla L. S t a c h o w i a k, Księga Izajasza II - III 40 60: Wstęp-przekład z oryginału-komentarz-ekskursy, PŚST IX,2, Poznań 1996, s. 282-283, podmiotem jest posłaniec. Ale zob. poniżej i J.L. K o o 1 e, Isaiah III, t. 3: Isaiah 56-66, s. 274. 
3 aby(m) dał opłakującym Syjon, aby(m) dał ${ }^{23}$ zawój zamiast popiołu, ${ }^{24}$ olej radości zamiast żałoby, szatęę $^{25}$ chwalenia (pieśni chwały) zamiast ducha słabego (zniechęcenia),

23 W G dla obu pierwszych półwierszy użyto tylko jednego czasownika

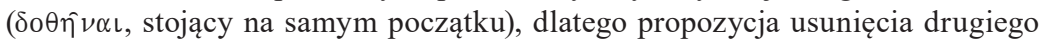
inf. cs. Co więcej, BHS proponuje również usunięcie wyrażenia „opłakującym Syjon”, będącego czymś w rodzaju dubletu (tak też K. K o e n e n, Textkritische Anmerkungen zu schwierigen Stellen im Tritojesajabuch, Biblica 69/1988, s. 567-568 , przy czym miałaby być to glosa precyzująca, że żałobnicy, o których jest mowa, to „opłakujących Syjon”; J. B 1 e n k i n s o p p, Isaiah 56-66, s. 219, dla którego לתת להם to alternatywne sformułowanie, które w jakiś sposób znalazło się w tekście), ale taka propozycja nie znajduje potwierdzenia w świadectwach tekstowych. Z dublujących się czasowników jeden ma dopełnienie dalsze, a drugi bliższe. Inaczej niż BHS - HAHAT i W. L a u, Schriftgelehrte Prophetie in Jes 56-66, s. 77-78, proponują skreślenie pierwszego z nich. Ale wtedy dopełnienie dalsze „opłakującym Syjon” stałoby przed inf. (lub przynależałoby do poprzedniej linii, wtedy wbrew G), dlatego W. Lau (tamże, s. 78 przyp. 249), przestawia לדתם dodatkowo kolejność słów. Według niego wraz z dodaniem tego inf. doszedł w kolejnej linii. Rekonstrukcja W. Lau’a tworzy gładki tekst, ale powstaje pytanie, jak mogło dojść do takich zakłóceń. Z kolei C. W e s t e r m a n n, Das Buch Jesaja: Kapitel 40-66, s. 290 przyp. 1, zmienia pierwszy czasownik na inf. pi. שֶמ tj. ,aby rozradować" (jako kontynuacja poprzedniej linii; podobnie L. S t a ch ow i a k, Księga Izajasza II - III, s. 284). Całą listę proponowanych skreśleń przedstawia J.L. K o o l e, Isaiah III, t. 3: Isaiah 56-66, s. 275-276, który ostatecznie opowiada się - w mojej ocenie słusznie - za TM i widzi w tym powtórzeniu klimaks. Jest to problem nie tekstowokrytyczne, lecz literackokrytyczny; tak też S. L a b o u v i e, Gottesknecht und neuer David: Der Heilsmittler für Zion und seine Frohbotschaft nach Jesaja 60-62, Forschung zur Bibel 129, Würzburg 2013, s. 44.

24 „Proch” jako symbol żałoby jest zwyczajowo tłumaczony właśnie słowem „popiół” (zob. HAHAT).

25 Co ciekawe, C. W e s t e r m a n n, Das Buch Jesaja: Kapitel 40-66, s. 290 (i najwyraźniej za nim ponownie L. S t a c h o w i a k, Księga Izajasza II-III, s. 264), nie odnotowując korekty wokalizacji, łączy ten rzeczownik z żałobą „okrycie żałobne", tak by oba metaforyczne sformułowania należały do poprzedniej linii. Trudno sobie wyobrazić jednak taką apozycję (,żałoba, okrycie”). Choć mamy do czynienia z hapaxl., to czasownik, od które jest wyprowadzany - עטה (HAHAT), bynajmniej nie sugeruje skromnego odzienia (takiego jak wór w Iz 3,24) - tak 
tak że będą nazywani ${ }^{26}$ dębami ${ }^{27}$ sprawiedliwym, plantacją JHWH, aby się wsławił. ${ }^{28}$

4 I odbudują ruiny na wieki, ${ }^{29}$ spustoszenia ${ }^{30}$ pierwszych podniosą i odnowią miasta zniszczone, spustoszenia na wiele kolejnych pokolen. ${ }^{31}$

5 I powstaną obcy, i będą paść stado wasze, i cudzoziemcy ${ }^{32}$ będą rolnikami waszymi i winiarzami waszymi. ${ }^{33}$

6 A wy kapłanami JHWH zostaniecie nazwani, „stojący w służbie Boga naszego" - powiedzą o was; bogactwem narodów będziecie się żywić i chwałą ich będziecie się chełpić. ${ }^{34}$

J.L. K o o 1 e, Isaiah III, t. 3: Isaiah 56-66, s. 277, słusznie odrzucając ewentualną korektę.

${ }^{26} \mathrm{~W} \mathrm{Q}^{\mathrm{a}}$ pf. con. q. 3. os. pl., co choć jest innym wariantem, to znaczeniowo identycznym (z podmiotem nieokreślonym). Vrs wspierają TM. Zob. J. B 1 e n k i n s o p p, Isaiah 56-66, s. 219.

27 Potężne drzewo, ogólne określenie dla terebintu, dębu czy palmy, tj. potężnego drzewa, które występuje jeszcze w Iz 1,29; 57,5 (zob. HAHAT), dlatego J. Blenkinsopp (tamże, s. 219-220), tłumaczy „mocnymi i wytrzymałymi dębami”.

28 Lub „okazać się wspaniałym” (zob. HAHAT).

29 Wydawałoby się, że najlepiej tłumaczyć konstrukcję jako oְ (przymiotnikowo): ,ruiny prastare”, ale zob. poniższa interpretacja. Tłumaczę oba rzeczowniki jako odrębne dopełnienia, drugi z nich jako acc. przysłówkowy.

30 Nie rzeczownik (por. 6,11), lecz ptp. pl. fem. w znaczeniu rzeczownikowym „ruiny”, „zniszczenie” (por. 49,19, też 49.8 itd.; zob. HAHAT).

$31 \mathrm{~W}^{\mathrm{a}}$ stoi na końcu powtórzony czasownik יקוממו (BHS; J. B l e n k i n s o p p, Isaiah 56-66, s. 220, który sądzi, że jest to dittografia). Dosł. końcowe sformułowanie: „z pokolenia na pokolenie” - do powyższego przekładu zob. poniższa interpretacja.

32 Dosł. „synowie/dzieci obcokrajowca/ów”, ale Đెּ może też wskazywać na przynależność do jakiejś grupy (zob. np. HAHAT).

$33 \mathrm{~W}$ przekładzie przejęto podział na półwiersze za BHS, choć akcent masorecki zakłada 4 krótkie linie $(2+2 / 2+2)$.

34 Tekst jest niepewny - czasownik rmy pojawia się jeszcze tylko w hi. w Jr 2,11 jako forma poboczna מור hi. (,zamieniać”, „wymieniać”, a także „zmieniać”, „chwiać się"), co tutaj raczej nie wchodzi w grę (inaczej J.L. K o o le, Isaiah III, t. 3: Isaiah 56-66, s. 284, który rozumie czasownik jako opis zmieniania ubrania 
7 Za ${ }^{35}$ hańbę „ich”36 - podwójne (odszkodowanie),

na nowe, co miałoby wyrażać chwałę kapłańską - taka interpretacja, jaki i domyśle ubrania są jedynie spekulacjami; W. L a u, Schriftgelehrte Prophetie in Jes 56-66, s. 81 przyp. 272 i S. L a b o u vi e, Gottesknecht und neuer David, s. 46, którzy czasownik z TM rozumieją jako „wystąpić”). Już prędzej moglibyśmy mieć do czynienia z אמר (,chełpić się”, „podnosić się z dumą”, który w Starym Testamencie występuje tylko w Ps 94,4, i to w hitp.), czego poświadczeniem mogą być q', S i Ms (Blombergiana). Podobnie można by postulować formę poboczną czasownika, który dobrze odpowiadałby paralelnemu אכל, wywodzonego z języka akadyjskiego i ugaryckiego: מרא (,tuczyć”, ,być tłustym/zdrowym”). Jednak jego istnienie nie jest potwierdzone w biblijnym hebrajskim (w misznaickim hebrajskim istnieje hrm), ale takie rozumienie może znajdować potwierdzenie w o' (zob. HAHAT). To ostatnie rozwiązanie przyjmuje K. K o e n e n, Textkritische Anmerkungen zu schwierigen Stellen im Tritojesajabuch, s. 586-570 czy BHS (obok dużo mniej prawdopodobnego, bo wywiedzionego z języka arabskiego i w hebrajskim niepotwierdzonego מיר, „Zaopatrywać w dobra”). Z kolei C. W e s te r m a n n, Das Buch Jesaja: Kapitel 40-66, s. 293 przyp. 2, a za nim L. S t a c h o w i a k, Księga Izajasza II - III, s. 285, zmieniają na hitp. הדר (por. Prz 25,6), tj. ,przyozdobicie się". Ze względu na potwierdzenie w Starym Testamencie najlepiej jest przyjąć, że w TM stoi forma poboczna (tak też J. B 1 e n k i n s o p p, Isaiah 56-66, s. 220).

35 BHS chciałoby bez oparcia w świadectwach dodać jeszcze spójnik כִ כִ (chyba jako uzasadnienie dla w.7b). C. W e s t e r m a n n, Das Buch Jesaja: Kapitel 40-66, s. 293 (i L. S t a c h o w i a k, Księga Izajasza II - III, s. 286) zdaje się w takim znaczeniu odczytywać תִּ, ale zob. HAHAT. Przyimek możne dotyczyć też kolejnych członów paralelizmu (do tego E. Kautsch /oprac./, Wilhelm Gesenius' Hebräische Grammatik, Georg Olms Verlag, Hildesheim-Zürichp-New York 199128, § 119hh, który wymienia przy tym Iz 61,7). Zob. kolejne przypisy.

${ }^{36} \mathrm{Z}$ powodu paralelnego półwiersza zaskakuje suf. 2. os., który musiałby się odnosić do kapłańskiego ludu z w.6, zaś 3. os. do obcych narodów z w.5, co oznacza, że w ramach paralelizmu mowa byłaby o dwóch różnych grupach. Jednak takiego sensu w.7a nie dałoby się pogodzić z w.7b. Najczęściej koryguje się suf. 2. os. na 3. os. (BHS; C. W e s t e r m a n n, Das Buch Jesaja: Kapitel 40-66, s. 293 przyp. 3; W. L a u, Schriftgelehrte Prophetie in Jes 56-66, s. 82; J. B l e n k i n s o p p, Isaiah 56-66, s. 220), ale bez jakiegokolwiek wsparcia świadectw. Dlatego nie może dziwić, że możliwości korekty zaprzecza O.-H. S t e c k, Der Rachtetag in Jesaja 61,2: Ein Kapitel redaktionsgeschichtlicher Kleinarbeit, w: t e n ż e, Studien zu Tritojesaja, s. 106-107 przyp. 3; za TM opowiada się też S. L a b o u v i e, Gottesknecht und neuer David, s. 47. Z kolei K. K o e n e n, Textkritische Anmerkungen zu schwierigen Stellen im Tritojesajabuch, s. 118 przyp. 356, zdaje się dopuszczać oba rozwiązania: l. difficilior lub korektę na 3.os., a L. S t a c h ow i a k, Księga 
zniewagę - będą się głośno radować nagrodą swoją (udziałem ich), ${ }^{37}$ dlatego w kraju swoim podwójne obejmą dziedzictwo, radość wieczną będą mieć.

8 Bo (tak) ja jestem JHWH, kochający prawo, nienawidzący rabunku występnego, ${ }^{38}$ tak że dam nagrodę (rekompensatę) ich w wierności/rzeczywiście i przymierze wieczne zawrę z nimi.

9 I będzie znane (uznane) wśród narodów potomstwo ich i latorośle (potomkowie) ich pośród ludów.

Izajasza II - III, s. 286, bez żadnej uwagi tłumaczy całość w.7 w 2. os. (raczej nie kierując się Q ${ }^{a}$ i S; do tego S. Labouvie). Jednak zarówno paralelność w w.7a, jak w zestawieniu w.7a/7b (por. מְשְנִ i radość), każą widzieć w tym wierszu widzieć pewną całość. Do znaczenia מִשְנְׁ zob. kolejny przypis i poniższą interpretację.

${ }_{37} \mathrm{Z}$ powodu לכן na początku w.7b oraz nietranzytywnym znaczeniem רנן w q. chętnie widziałoby się tutaj wyrażenie ,zniewaga i opluwanie” (zob. Iz 50,6; Mi 2,6), tj.: ,zniewaga i opluwanie udziałem ich” (tak BHS: prp; C. W e s t e r m a n n, Das Buch Jesaja: Kapitel 40-66, s. 293 i przyp. 4; L. S t a c h o w i a k, Ksiega Izajasza II - III, s. 286), a wtedy מִשֵֶׁ byłoby apozycją (podwójny wstyd miałby współgrać z dwoma rzeczownikami dla szyderstwa w drugim półwierszu - do tego J.L. K o o l e, Isaiah III, t. 3: Isaiah 56-66, s. 285). Ponieważ korekta taka nie ma wsparcia w świadectwach tekstowych, lepiej trzymać się TM - tak też K. K o e n e n, Textkritische Anmerkungen zu schwierigen Stellen im Tritojesajabuch, s. 570-571, który לכֵ na początku w.7b rozumie emfatycznie (por. też W. L a u, Schriftgelehrte Prophetie in Jes 56-66, s. 83), a nietranzytywne znaczenie czasownika w q. postuluje na podstawie tranzytywnego użycia pi. Możliwe jest więc dwojakie ujęcie TM: 1) משְׁנֶה jako apozycja: ,za «ich» wstyd podwójny i zniewagę będą radować się udziałem swoim" (tak Lau; J. Blenkinsopp; HAHAT); 2) jak powyższy przekład, który zdaje się być wspierany przez akcent masorecki (tak K. Koenen).

38 Dosł.,„W przestępstwie/nieprawości”. Oboczna wokalizacja עִ עְ pojawiająca się w kilku Mss (por. BHS) obecna jest też w pl. w Ps 58,3; 64,7 (zob. HAHAT). Takie odczytanie tego rzeczownika potwierdza wiele świadectw, do czego prawdopodobnie niepotrzebna jest korekta wokalizacji (wbrew BHS i S. L a b o u v i e, Gottesknecht und neuer David, s. 48 - HAHAT czy J.L. K o o l e, Isaiah III, t. 3: Isaiah 56-66, s. 289, uzasadniając to dodatkowo So 3,5 i Pwt 32,4). Zaś A. S p a n, Die Stadtfrau Zion im Zentrum der Welt: Exegese und Theologie von Jes 60-62, BBB 175, Göttingen 2015, s. 248, przyp. 954, za pierwotną uznaje „ofiarę całopalną”, co ma sygnalizować subtelną krytykę kultu, co zwłaszcza w uzasadnieniu do w.7 jest niemożliwą interpretacją. 
wszyscy widzący ich rozpoznają ich, że są oni potomstwem, które pobłogosławił JHWH. radośnie wykrzykiwać będę $e^{39}$ wogu moim, bo przyodział mnie w szaty zbawienia, tuniką sprawiedliwości okrył mnie, ${ }^{40}$ jak pan młody, który sprawuje urząd kapłana z zawojem, ${ }^{41}$ jak panna młoda, która przyozdabia się rzeczami swoimi. ${ }^{42}$

39 Dosł.: „będzie dusza moja”

40 Wokalizacja TM zdaje się wskazywać na pf. (z suf.) hapaxl. יעט,, który jest prawdopodobnie formą oboczną עטה ${ }^{1}$ hi. (HAHAT; J.L. K o o 1 e, Isaiah III, t. 3: Isaiah 56-66, s. 293). Jednak częściej unika się tego hapaxl., proponując korektę na pf. q. lub impf. hi עטה', i to pomimo nieprzechodniego znaczenia tego czasownika (najwyraźniej postulując jego tranzytywne znaczenie: BHS; do tego też J.L. Koole, który przywołuje ponadto propozycję, by w TM widzieć tzw. forma mixta, tj. formę mieszaną pf. q/impf. hi., mającą pozostawiać wybór czytelnikowi; W. L a u, Schriftgelehrte Prophetie in Jes 56-66, s. 88 przyp. 313).

${ }^{41}$ TM zdaje się niejasny, dlatego postuluje się korektę czasownika na יכין (BHS; C. We s t e r m a n n, Das Buch Jesaja: Kapitel 40-66, s. 293 przyp. 5; L. S t a c h ow i a k, Księga Izajasza II - III, s. 287) lub יכנין: (W. L a u, Schriftgelehrte Prophetie in Jes 56-66, s. 87-88 przyp. 310, w tranzytywnym znaczeniu „zakładać”). Obie korekty odnotowane zostały w HAHAT: w znaczeniu „mocować”, tj. „obwiązywać turban” czy „zakładać turban”. Jednak turban może być elementem stroju kapłana (zob. poniżej), a J.L. K o o 1 e, Isaiah III, t. 3: Isaiah 56-66, s. 294, zwrócił uwagę, że proponowany czasownik nie jest odpowiedni dla ubrania (w Hi 27,16-17 ma inny sens). Świadectwa tekstowe nie są tutaj pomocne (omówione w J.L. Koole). Pozostanie przy TM pozwalałoby postrzegać „,zawój” jako kolejne dopełnienie czasownika z poprzedniej linii: ,[okrył] jak pana młodego, który sprawuje urząd kapłana, zawojem”, ale wtedy oba paralelne porównania miałyby inną konstrukcję i zależności składniowe. Chyba najlepszym rozwiązaniem jest potraktowanie „zawoju” jako acc. przysłówkowy (dla „okoliczności” działania; rozwiązanie takie wcale nie jest nowe - do tego W. L a u, Schriftgelehrte Prophetie in Jes 56-66, s. 87, przyp. 309; jedna z propozycji J.L. Koole'a, który proponuje alternatywnie, by przyjąć tranzytywne znaczenie czasownika כהן [?], co miałoby się przypuszczalnie sprowadzać do tłumaczenia J. Blenkinsoppa /Isaiah 56-66, s. 227-228/: ,założył turban jak kapłan”). Byłoby to porównanie dla radości proroka, powiązane z zakładaniem czy noszeniem odświętnych szat.

${ }_{42}$ Może chodzić o ubrania (por. Pwt 22,5) czy inne ozdobne przedmioty (por. HAHAT). Zob. poniższą interpretację. 
11 Bo jak ziemia wyprowadza pęd swój

i jak ogród sprawia, że zasiewy jego wypuszczają pędy, tak Pan, ${ }^{43}$ JHWH sprawi(a),${ }^{44}$ że wypuszcza pędy sprawiedliwość i pieśń chwały wobec wszystkich narodów.

\section{Komentarz}

Wiersz 1. Mówiący przedstawia siebie jako obdarzonego duchem Bożym. Wyrażenie o spoczywającym duchu Bożym ma paralelę w pierwszej Pieśni o słudze Pana $(42,1)$, gdzie jest wyposażeniem sługi umożliwiającym wypełnienie zadania (też Mi 3,8). ${ }^{45}$ Duch wskazuje na królewską godność posłańca (1Sm 16,13-14 i w odniesieniu do przyszłego władcy Iz 11,2), ${ }^{46}$ a jego misja tak samo jak we wspomnianej Pieśni o słudze realizowana jest przede wszystkim przez zwiastowanie (Iz 42,2-3). Mówiący tak jak sługa JHWH, pełni więc funkcję prorocką (por. też Iz 59,21; dalej Lb 11,25.29). ${ }^{47}$ Tym razem posłużono się zdaniem rzeczownikowym, tak że mowa jest

43 W. L a u, Schriftgelehrte Prophetie in Jes 56-66, s. 88 przyp. 314, ponownie

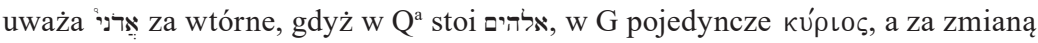
miałoby przemawiać także metrum. Do tego powyższa uwaga do w.1. w mojej ocenie $\mathrm{Q}^{\mathrm{a}}$ pośrednio potwierdza TM.

44 Impf. może być tłumaczone zarówno w czasie teraźniejszym, jak i przyszłym (użycie impf. w obrazie z pierwszej części wiersza skłaniałoby do ujęcia w czasie teraźniejszym).

45 C. We s t e r m a n n, Das Buch Jesaja: Kapitel 40-66, s. 291, właśnie w Mi 3,8 widzi najbliższą paralelę.

46 Do tego przede wszystkim O. K a i s e r, Der königliche Knecht. Eine traditionsgeschichtlich-exegetische Studie über die Ebed-Jahwe-Lieder bei Deuterojesaja, FRANT 70, Vandenhoeck \& Ruprecht, Göttingen $1962^{2}$, s. 18-31, tutaj zwł. s. 22-23; K. E11 ig e r, Deuterojesaja, s. 204-205.

47 W Iz 42,1-4 dochodzi do zlania się elementów charyzmatycznych, królewskich z urzędem prorockim - R. A 1 b e r t z, C. W e s t e r m a n n, 꽤, w: E. J e n n i, C. W e s t e r m a n n (wyd.), Theologisches Handwörterbuch zum Alten Testament, t. II, Chr. Kaiser Verlag/Theologischer Verlag, München-Zürich 1984, kol. 726-753, 726-727, 750 (dalej: THAT).. Wyrażenie to w innym sensie pojawia się też w Iz 44,3. 
o stałym obdarowaniu duchem Bożym. ${ }^{48}$ Przemawiający wzoruje się zatem na królewskim słudze-proroku z Iz 42,1.49 Złożenia imienia JHWH z ארני z k kóry również może pełnić rolę imienia Bożego, jest dość częste w Starym Testamencie, co więcej, trzy razy pojawia się w trzeciej Pieśni o słudze (Iz 50,4.5.9) czy w Iz 48,12 w powiązaniu z posyłaniem proroka (identyczna forma gramatyczna) wraz z duchem Bożym. Boże „podwójne” imię zdaje się zatem wiązać ze zwiastowaniem prorockim, ${ }^{50} \mathrm{a} \mathrm{w}$ szczególności z prorocką misją sługi JHWH, którego Bóg wspiera i ratuje. Co więcej, stojąc także w w.11b tworzy klamrę kompozycyjną, spinającą całym ten rozdział i podkreślającą, że nadchodzącym zbawieniu jest Bożym dziełem. Wyposażenie duchem wynika z namaszczenia przez JHWH (pf.). משח, który jest wielokrotnie ekwiwalentem מלק hi., jest tak samo jak rzeczownik מש: związany w szczególności z instytucją króla (np. Ps 45,8), zaś o namaszczeniu proroka mowa jest jeszcze jedynie w $1 \mathrm{Krl} 19,16^{51}$ (przy czym w naszym wierszu pomazanie trzeba rozumieć w sensie przenośnym). ${ }^{52}$ Co ciekawe, suf. nie połączono z czasownikiem, ale $\mathrm{z}$ notą acc., co być może ma podkreślać rolę i znaczenie posłańca. ${ }^{53}$

48 Zob. też J.L. K o o le, Isaiah III, t. 3: Isaiah 56-66, s. 269.

49 W. L a u, Schriftgelehrte Prophetie in Jes 56-66, s. 69, zauważając, że posiadanie ducha w wypowiedziach prorockich ma swój Sitz im Leben w apologetyce, wysuwa przypuszczenie, że prorok, który tutaj przemawia, musiał przeciwstawić się podejrzeniu o bycie fałszywym prorokiem. Jednak związki z Pieśniami o słudze Pana wystarczająco wyjaśniają posłużenie się tym królewskim z pochodzenia motywem.

50 Zob. J.L. K o o 1 e, Isaiah III, t. 3: Isaiah 56-66, s. 269.

51 Do tego pojęcia J.A. S o g g i n, מלל, w: THAT, t. I, kol. 908-920, tutaj kol. 913-914: o pomazaniu króla mowa jest w sumie 32 razy w Biblii Hebrajskiej (poza Iz 45,1 zawsze izraelskiego/judejskiego króla, przy czym najwyraźniej przeoczono 1Krl 19,15), poza tym kapłana (arcykapłana) czy patriarchy. W przypadku króla wiąże się z tym jego nietykalność, a czasami również dar ducha (1Sm 16,13).

52 Słusznie C. W e s t e r m a n n, Das Buch Jesaja: Kapitel 40-66, s. 291. Nigdzie indziej prorok nie mówił o sobie jako pomazańcu Bożym - J.L. K o o 1 e, Isaiah III, t. 3: Isaiah 56-66, s. 270.

53 Zob. tami̇e, s. 269. 
Paralelnie mowa jest o posłaniu - $-\pi^{54}$ a ponowne użycie pf. wskazuje, że mówiący te słowa już został namaszczony i wysłany przez Boga. Zadanie posłańca polega na zwiastowaniu, ogłaszaniu - בשר pi., który bardzo często dotyczy zwiastowania radosnej wiadomości (Iz 40,9; 52,7;55 41,27; też 60,6; Ps 96,2). ${ }^{56}$ Następujące dalej inf. nie pozostawiają wątpliwości, że także tutaj oznacza przekazanie zbawiennej wieści. Dwukrotnie użyty czasownik קרא występuje również w celu zwiastowania prorockiego (np. Iz 40,6; Jr 2,2; 3,12; $1 \mathrm{Krl} 13,32),{ }^{57}$ niosącego zbawcze przesłanie (Iz 40,2; 58,1). Wyrażenie דִ דרוֹר występuje jeszcze w Kpł 25,10 i Jr 34,8.15.17 w celu ogłoszenia (wydania dekretu) uwolnienia niewolnika w roku jubileuszowym (siódmym lub pięćdziesiątym; por. też Ez 46,17), ${ }^{58}$ tj. przywrócenia wolności i zwrot

54 Oznacza zasadniczo wysłanie kogoś z misją, nieraz proroków (np. Iz 6,8 czy 48,16). Szerzej na podstawie tego czasownika K. K o e n e n, Ethik und Eschatologie im Tritojesajabuch, s. 104-105, uzasadnia, że powołanym jest tutaj prorok.

55 W których zwiastunką jest Syjon/Jerozolima, z czego O.-H. S t e c k, Der Rachtetag in Jesaja 61,2, s. 107 przyp. 4, s. 111 przyp. 22 , s. 117 przyp. 43, dowodząc literackiej zależności od 40,1-9, wnioskuje o tożsamości mówiącego ,ja”, którym jest Syjon (tak też A. S p a n, Die Stadtfrau Zion im Zentrum der Welt, s. 210-214). Taka interpretacja jest jednak problematyczna: 1) w zestawieni z „opłakującym Syjon" (O.-H. Steck uznaje wyrażenie to za wtórne; do tego zob. poniżej) okazałoby się, że spersonalizowany Syjon ma do wypełnienia zadanie wobec tych, którzy go opłakują - metaforyka byłaby niespójna, bo „zmarły” ma pocieszać „żałobników”; 2) jak rozumieć „namaszczenie” i „obdarzenie duchem” spersonalizowanego Syjonu? Jeszcze mniej przekonuje teza, że Iz 61,1-3 ma być realizacją tego, do czego Syjon został wezwany w 60,1-3, stając się światłem dla uwięzionych w ciemności (tak A. S p a n, Die Stadtfrau Zion im Zentrum der Welt, s. 214, która sama zauważa, że w 61,1-3 całkowicie brak metaforyki światła). Do tego krytycznie już W. L a u, Schriftgelehrte Prophetie in Jes 56-66, s. 67,73 (s. 70 przyp. 210, gdzie odnotowuje ponadto krytycznie koncepcję utożsamienia posłańca z kapłanem).

56 Dlatego w G przekład jako €ن่ $\alpha \gamma \gamma \epsilon \lambda i ́ \sigma \alpha \sigma \theta \alpha \iota$ (aor.). Do tego czasownika zob. R. Fi c k e r, מַלְּאָ, w: THAT, t. I, kol. 900-907, zwł. kol. 903-904.

57 Jako terminus technicus - C.J. L a b u s c h a g n e, arq, w: tamże, t. II, kol. 666-674, zwł. kol. 667-669.

58 Zob. J.L. K o o 1 e, Isaiah III, t. 3: Isaiah 56-66, s. 273. 
własności (utraconej w wyniku długów)..$^{59}$ Choć posłaniec przedstawia siebie za pomocą królewskich wątków, to raczej nie chodzi tutaj o wydanie królewskiego dekretu, lecz o prorockie ogłaszanie wyzwolenia spod jarzma wszelkiej niewoli. ${ }^{60}$ Za paralelnym kryje się prawdopodobnie rdzeń Iz 42,20, z dopełnieniem „oczy” (jak w Iz 42,7), ${ }^{61}$ tak że trzeba przypuszczalnie zakładać takie domyślne dopełnienie: oczy po wyjściu z długotrwałej ciemności (jak w Iz 42,7 i 49,9 określono więzienie) powoli zaczynają widzieć. ${ }^{62} \mathrm{~W}$ w.1 działalność posłańca opisuje jeszcze czasownik חבש (pi.). który oznaczał m.in. obwiązywanie ran czy złamań (zob. Iz 1,6). W Starym Testamencie Bóg jest tym, który rani i leczy (Iz 30,26; por. Ps 147,3). ${ }^{63}$ Zadaniem posłańca jest uleczenie, podniesienie na duch tych, którzy są załamani. Być może czasownik ten trzeba też kojarzyć z końcem żałoby, o której mowa jest w w.2b-3a. Ponieważ sąsiednie czasowniki oznaczają zwiastowanie dobrej wiadomości, to środkiem podniesienia na duchu, wyrwania ze zniechęcenia, są słowa prorockie.

Do interpretacji tych wersetów ważny jest opis adresatów. אענו (forma poboczna אעני) odnosi się do biednego, uciskanego, nieznaczącego czy pogardzanego, tj. ma wymiar materialny i społeczny. Bóg jednak otaczał biedaków opieką (np. Ps 34,7). Termin ten zyskał dodatkowy sens religijno-etyczny w okresie powygnaniowym (por.

59 To znaczenie czyni ośrodkiem swej interpretacji, podporządkowując mu pozostałe motywy i wyrażenia, O.-H. S t e c k, Der Rachtetag in Jesaja 61,2, s. 108-118, zwł. 108-110.

60 W. L a u, Schriftgelehrte Prophetie in Jes 56-66, s. 73, widzi w tym eschatologizację wyrażenia, mającego mówić o uwolnieniu w ogóle.

${ }_{61}$ Zob. powyższą uwagę do tłumaczenia.

62 Tak J.L. K o o l e, Isaiah III, t. 3: Isaiah 56-66, s. 272-273. Jednak wyjątkowość konstrukcji w 42,20 nakazuje ostrożność.

${ }^{63}$ A także oznaczał siodłanie, zawiązywanie pasów siodła na ośle czy oślicy (np. Lb 22,21), zakładanie zawoju na głowie (Wj 29,9), czasami na znak zakończenia żałoby (Ez 24,17); zob. G. M ü n d e r l e i n, חבש, w: G. J. B o t t e r w e c k, H. R i n g g r e n, H.-J. F a b r y (wyd.), Theologisches Wörterbuch zum Alten Testament, Verlag W. Kohlhammer, Stuttgart-Berlin-Köln-Mainz 1973-2016, t. II, kol. 726-730 (dalej: TWAT). 
Ps 25,9), biedak stał się „,biednym JHWH”, czyli pobożnym, a tym samym powstał ścisły związek między pogardzanym biedakiem a ludem Bożym. ${ }^{64}$ Posłaniec ma na uwadze osoby pokrzywdzone ekonomicznie i społecznie, ${ }^{65}$ ale możemy mieć ponadto do czynienia z określeniem ludu Bożego, nad którym Boga roztacza opie-

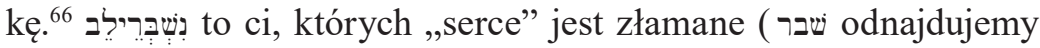
w Iz 42,3), chodzi więc o stan umysłu i emocji, świadomość czy poczucie bezsilności - w obliczu wrogów $(\mathrm{Jr} 23,9)$ czy nieprawych (Ps 34,22). W Ps 147,3 określono w ten sposób rozproszonych mieszkańców Jerozolimy, których Bóg uzdrawia, dodając im siły. ${ }^{67} \mathrm{Oba}$ terminy w paralelnych liniach wskazują zatem na bezsilność w obliczu przeciwników, przy czym drugi z nich dotyczy subiektywnego poczucia ${ }^{68}$ i kojarzone są z wygnańcami. Następne określenie שִ שִבוּים odnosi się do jeńców wojennych ${ }^{69}$ a ptp. fem. w Iz 49,24-25 i 52,2 do wygnanych „dzieci Jerozolimy”, jej byłych mieszkańców czy raczej ich potomków (słowo to nie zostało użyte dosłownie). Słowo ,więźniowie” (od rdzenia אסר - ,zakuć”, „Związać”)70 pojawia się w Iz 49,9, gdzie odnosi się do wygnańców babilońskich i być może rozproszonej po świecie diaspory izraelskiej. Wszystko to razem wskazuje na to, że odbiorcami zwiastowania posłańca są wygnańcy babilońscy, być może wraz ze wszystkimi rozproszonymi, którzy jak w Iz 42,7 i 49,9 są postrzegani jako więźniowie, pozbawieni sił i znaczenia (do

64 Do tego pojęcia R. M a r t i n - A c h a r d, ענה II, w: THAT, t. II, kol. 341-350.

65 L. S t a c h ow i a k, Księga Izajasza II - III, s. 283, sądzi, że chodzi o ludzi upośledzonych socjalnie, których liczba po wygnaniu musiała wzrosnąć.

${ }_{66}$ Podobnie J.L. K o o 1 e, Isaiah III, t. 3: Isaiah 56-66, s. 271.

${ }^{67}$ A w q. w Ps 51,19; 69,21 dla proszących o wybaczenie grzechów.

${ }_{68} \mathrm{Na}$ co zwróciła uwagę A. S p a n, Die Stadtfrau Zion im Zentrum der Welt, s. 2018 .

${ }^{69}$ Do hbv B. O t z e n, שבה, w: TWAT, t. VII, kol. 950-958: w literaturze prorockiej najczęściej w odniesieniu do wygnańców babilońskich, z wyjątkiem Iz 20,4 i Na 3,10.

70 J.L. K o o 1 e, Isaiah III, t. 3: Isaiah 56-66, s. 272. 
tego zob. jeszcze poniżej). ${ }^{71}$ Słowo posłańca ma nieść im uwolnienie, podniesienie na duchu i przywrócenie wcześniejszego stanu.

Wiersz 2a. Posłaniec ma ogłaszać (drugi raz קרא) łaskę i zemstę JHWH, a ściślej, że nadszedł czas im wyznaczony. Choć zarówno rok, jak i dzień nie muszą oznaczać dosłownie jednego roku i jednego dnia, tylko jakiś czasu (paralelnie w Iz 34,8), ${ }^{72}$ to zwraca uwagę, że znacznie dłuższy rok wiąże się z Bożą przychylnością, a krótszy dzieńn ${ }^{73} \mathrm{z}$ karą (tak samo jak w Iz 63,4). znaczenie jako określenie czasu zbawienia, tak samo jak w Iz 49,8, ${ }^{74}$ gdzie stoi paralelnie do ישוּאעה, zbawienia (por. też 60,10, w którym znakiem Bożej przychylności stojącej w opozycji do Bożego karania jest odbudowa murów Jerozolimy przez cudzoziemców i służba ich władców). Nieco zaskakujący jest antytetyczny dzień zemsty Bożej, co wydaje się stanowić motyw nie znajdujący żadnego odzwierciedlenia w tej perykopie. ${ }^{75}$ Rdzeń נקם, który prawdopodobnie pochodzi

71 Czemu niesłusznie zaprzecza K. K o e n e n, Ethik und Eschatologie im Tritojesajabuch, s. 108-109, dlatego że zakładał, iż Triz miał mieć na względzie problemy jerozolimskiej społeczności powygnaniowej, tj. o dłużników, ale zwiastowanie zbawienia dotyczy całego ludu, tak że ma chodzić o koniec wszelkiego ucisku. Zastanawia przy tym, że pojęciu „więźniowie” nie poświęcił żadnej uwagi. Już C. We s te r m a n n, Das Buch Jesaja: Kapitel 40-66, s. 292, twierdził, że adresatami nie są wygnańcy, ale więzieni za długi lub innego rodzaju ,jarzmo” jak w 58,6. Jednak słownictwo w rozdz. 58 jest odmienne, a za długi popadano raczej w niewolę, a nie trafiało się do więzienia (nawet jeśli więzienie jako takie miałoby słabo pasować do wygnańców - U. B e r g e s, Jesaja 49-55, s. 50, ale zob. Iz 10,4; 14,17; 24,22; por. też 22,3, który uświadamia, że uwięzienie mogło być rozumiane dość szeroko). Ponownie J. B l e n k i n s o p p, Isaiah 56-66, s. 223-225, myślał przede wszystkim o ubogich w Judei okresu babilońskiego (por. Ne 5,1-5), utożsamianymi również z pobożnymi. L. S t a c h o w i a k, Księga Izajasza II-III, s. 283, w trochę nieokreślony sposób odnosi użyte tutaj pojęcia zarówno do deportowanych, jak i więzionych za długi. Wydaje się, że interpretacje nie godzące się na odniesienie do wygnańców uzależnione są od datowania (Tr)Iz 56-66.

72 Do tego E. J e n n i, ai’, w: THAT, t. I, kol. 707-726, tutaj kol. 711.

73 Zob. tamże, kol. 722.

74 Do tego pojęcia zob. G. G e r 1 e m a n, רצ', w: THAT, t. II, kol. 810-813.

75 O.-H. S t e c k, Der Rachtetag in Jesaja 61,2, s. 106-108, który uznaje linię za wtórną korektę (nie znajduje dla niej uzasadnienia także w rabunku z w.8ab). Jednak 
z języka prawnego dla kary wyrównującej popełnione przestępstwo, może opisywać Boże karanie narodów za wrogość wobec jego ludu (np. Lb 31,2; zwłaszcza w tekstach wygnaniowo-powygnanniowych, takich jak Iz 34,8; 35,4; 47,3), co może nieść ze sobą pocieszenie dla pogrążonego w żałobie ludu, uciśnionego i więzionego (Iz 61,2 i 63,4$).{ }^{76}$ Można przypuszczać, że uwolnienie i pocieszenie „wszystkich żałobników" zakłada nie wyrażoną tutaj wprost odpłatę na wrogach Izraelitów czy wygnańców (jak w Iz 47,3-4). ${ }^{77}$ A jeśli kluczowe znaczenie miało zróżnicowanie na dzień i rok, to myśl ta mogłaby wyrażać przekonanie, że Boża kara trwa krótko w porównaniu z Jego miłosierdziem (por. Wj 20,5-6; Pwt 5,9-10; 7,9-10). Boża kara w postaci zniszczenia Syjonu i wygnania okazuje się małoznacząca wobec bogactwa Bożej przychylności. Ponieważ JHWH nazywany jest „naszym Bogiem”, to przemawiający posłaniec uważa siebie za przynależącego do pocieszanej wspólnoty.

Wiersz 2b. W TM jest łączony z w. 2a, tak że zdaje się stanowić rodzaj tymczasowego podsumowania. ${ }^{78}$ Jednak rzeczowo motyw

obserwacja taka nie może być powodem korekt tekstowych zarówno ze względu na brak poświadczenia, jak i zasadę lectio difficilior - zob. do tego też J.L. K o o l e, Isaiah III, t. 3: Isaiah 56-66, s. 271. Co więcej, zdaje się tworzyć z poprzednim półwierszem paralelizm.

76 Zob. G. S a u e r, נק, w: THAT, t. II, kol. 106-109, który do tekstów o zemście Bożej na wrogach Izraela zalicza też Iz 59,17, chociaż może w nim chodzić o wrogów wewnątrz samego Izraela (tak J.L. K o o 1 e, Isaiah III, t. 3: Isaiah 56-66, s. 202). Dzień zemsty jawi się jako bliski wyobrażeniu o dniu JHWH (Iz 13,6.9; Am 5 itd.) - do tego E. J e n n i, aי, kol. 723-724; C. W e s te r m a n n, Das Buch Jesaja: Kapitel 40-66, s. 292 czy J. B 1 e n k i n s o p p, Isaiah 56-66, s. 225; a dalej do wyrażenia „dzień zemsty” W. L a u, Schriftgelehrte Prophetie in Jes 56-66, s. 76, przyp. 238 oraz O.-H. S t e c k, Der Rachtetag in Jesaja 61,2, s. 110-116, który ostatecznie negatywnej ustosunkowuje się do związków z Iz 34,8; 47,3; 59,17; 63,4.

77 Zob. J.L. K o o le, Isaiah III, t. 3: Isaiah 56-66, s. 274. Inaczej C. W e s t e r m a n n, Das Buch Jesaja: Kapitel 40-66, s. 292, który chce rozumieć zemstę w pozytywnym sensie restauracji, przywrócenia wcześniejszego stanu, co jednak nie znajduje potwierdzenia w znaczeniu tego słowa, zawsze odnoszącego się do karzącej odpłaty.

78 Tak J.L. K o o le, Isaiah III, t. 3: Isaiah 56-66, s. 274. 
żałoby wiąże ten półwiersz z kolejnym wierszem i stanowi linię paralelną z kolejnym półwierszem. Powyżej zwrócono już uwagę na pytanie, kto jest podmiotem kolejnych wyrażeń w inf.: posłaniec, gdyż można czy trzeba je postrzegać jako podporządkowane w dalszym ciągu czasownikowi שִלחבְנ, czy JHWH z w.2a, tym bardziej że zamiana żałoby w radość jest raczej dziełem Boga, a nie posłańca. Gramatycznie pierwsza możliwość wydaje się być bardziej przekonująca. ${ }^{79}$ Treściowo trzeba wziąć pod uwagę prawdopodobną zależność od Iz 40,1-2, gdzie pocieszanie i zwiastowanie łączą się ze sobą nierozerwalnie. ${ }^{80}$ Można by też dostrzegać w pocieszaniu Boże współdziałanie ze posłańcem, któremu zlecił realizację tego zadania. ${ }^{81}$ Pocieszanie ( נחם pi.) odtwarza więzi społeczne i jest nierozerwalnie związane z udzielaniem konkretnej pomocy (por. Hi 42,11), choć może też dokonywać się za pomocą słów (też w Rdz 50,21; a nawet milczenia jak w Hi 2,11). ${ }^{82}$ Jest ono ważnym wątkiem Deuteroizajaszowym (Iz 40,1-2; 49,13; 51,12; 52,9 czy 51,3.19, gdzie obiektem jest Syjon). ${ }^{83}$ Poza towarzyszeniem żałobnikom posłaniec może pocieszać ich słowami, ale „rzeczową” pomoc mogą uzyskać jedynie od Boga. אבל, żałobnik to słowo odnoszące się do osoby w ciężkiej sytuacji straty i nieszczęścia (jeśli w uogólnionym sensie). ${ }^{84}$

79 Szereg inf. sięga aż do w.3 i są one podporządkowane wspomnianemu czasownikowi; zob. E. K a u t s ch (oprac.), Wilhelm Gesenius' Hebräische Grammatik, Georg Olms Verlag, Hildesheim-Zürich-New York 199128, § 114f-p, ale przyporządkowanie inf. z 1 może mieć bardzo luźny charakter (tamże, §114o).

${ }^{80}$ Do tego A. S p a n, Die Stadtfrau Zion im Zentrum der Welt, s. 210.

81 C. We s t e r m a n n, Das Buch Jesaja: Kapitel 40-66, s. 292; tak też interpretuje J.L. K o o l e, Isaiah III, t. 3: Isaiah 56-66, s. 27, nie podnosząc rozważanego tutaj problemu.

82 Zob. H.J. S t o e b e, נחם, w: THAT, t. II, kol. 59-66, zwł. kol. 61-63.

83 Zwraca uwagę, że pojawia się tylko w prologu i drugiej części Dtiz (49-55). W Triz w pi. jeszcze tylko w 66,13 .

${ }^{84}$ Najczęściej chodzi o żałobę po zmarłym (Rdz 37,35), ewentualnie o pokutę wobec innego strasznego nieszczęścia (Est 4,3; 9,22), też w uogólnionym sensie (jak w Mi 1,8). Do tego pojęcia F. S t o l z, אבל, w: THAT, t. I, kol. 27-31. 
Wiersz 3a. Doprecyzowano w nim, że mowa jest o opłakujących Syjon (podobnie Iz 66,10), ${ }^{85}$ podczas gdy w Iz 60,20 płaczącą jest sam Syjon (por. Tr 1,4). Potrzeba pocieszenia wynika zatem ze śmiertelnego nieszczęścia, które dotknęło Syjon, zniszczeniach, utraconych mieszkańcach, poległych czy wygnanych. W porównaniu z w.1 optyka kieruje się w stronę Syjonu, Jerozolimy. Czy opłakującymi są tylko wygnańcy i jej rozproszeni mieszkańcy (por. w.1), czy też i ci, którzy pozostali w Judzie? Dwa pierwsze dublujące się w TM inf. trzeba traktować przypuszczalnie jako emfazę. ${ }^{86}$ Chyba że linia ta miałaby być późniejszym, redakcyjnym uzupełnieniem, co powodowałoby, że znikłaby z w.1-3 wszelka wzmianka o Syjonie (który nie byłby wtedy w ogóle z nazwy wspominany w tym rozdziale). ${ }^{87}$ W trzech wyrażeniach z תח przedstawiono, co mają otrzymać żałobnicy (po Syjonie). Po pierwsze, zawój, być może turban, ${ }^{88}$ który był noszony przy świątecznych okazjach (zob. Iz 3,20), ale nigdy w czasie żałoby (Ez 24,17). ${ }^{89}$ Założenie, obwiązanie zawoju sygnalizuje koniec żałoby i radosne świętowanie. Tworzy tutaj grę słów ${ }^{90}$ z prochem, luźną ziemią, który byłe elementem rytu żałobnego (Hi 2,8; por. Iz 47,1 z bliskoznacznym עפר, od którego różni się tym, że poza jednym wyjątkiem nie oznacza popiołu) czy pokutnego (Jon 3,6;

85 Przymiotnik (w rzeczownikowym znaczeniu) stoi też w (Tr)Iz 57,18, a nie pojawia się w ogóle w Dtiz. J. B l e n k i n s o p p, Isaiah 56-66, s. 225, sądzi, że trzeba ich utożsamiać ze „sługami JHWH” i „drżącymi” (por. np. 66,14; por. też Ml 3,14), tj. jakąś sektą z połowy V w. p.n.e. (por. Ezd 9,4; 10,3), wzywającą do rygorystycznego przestrzegania szabatu (tamże, 51-54).

${ }^{86}$ J.L. K o o 1 e, Isaiah III, t. 3: Isaiah 56-66, s. 276, dla którego jest to klimaks, z tym że שים ujmować należałoby w sensie exhibere (,przedstawiania”), a נתן applicare („stosowania”). Zob. też powyższą uwagę do tekstu.

87 Zob. poniższe rozważania do krytyki literackiej.

88 Zob. HAHAT.

${ }^{89}$ Był noszony przede wszystkim przez kapłanów (w.10 oraz Wj 39,28; Ez 44,18); zob. też J.L. K o o l e, Isaiah III, t. 3: Isaiah 56-66, s. 277. Pojawia się tylko 7 razy w Starym Testamencie, natomiast częściej czasownik, w tym w hipt. w Iz 44,23; 49,3; 60,21 itd.; zob. również J. H a u s m a n n, פאר, w: TWAT, t. VI, kol. 494-499.

90 Tak też W. L a u, Schriftgelehrte Prophetie in Jes 56-66, s. 78; HAHAT. 
postu w 58,5). ${ }^{91}$ Po drugie, radość, które jest programowym pojęciem dla czasu zbawienia, stojącego w kontraście do obecnej, opłakanej sytuacji. Choć wywodzi się od rdzenia שיש, שיש / ulubionego w Triz (w tej perykopie jeszcze w w.10), to rzeczownik ten w Dti Triz występuje jedynie jeszcze w 51,3.11 (opisując radość Syjonu i powracających do niego, gdy Bóg odmienia ich los). ${ }^{92}$ Pojawia się w obrazowym sformułowaniu z שֶׁ (duża liczba spółgłosek syczących może być zabiegiem stylistycznym; identyczne sformułowaniu w Ps 45,8 jako środek משח, tak że autor się prawdopodobnie opierał na tym psalmie). ${ }^{93}$ Oliwa była jednym z podstawowych produktów (zwłaszcza w Palestynie) i kojarzyła się z obfitością, tłustością i sytością, używana była także jako środek kosmetyczny (Pnp 1,3; 4,10) i medyczny (Iz 1,6), kojarzony z przyjemnością i leczeniem ran. ${ }^{94}$ Dlatego obrazowo pasuje do nowego czasu zbawienia naznaczonego radością, która zastąpi żałobę. Więcej, w sensie przenośnym mogła służyć do leczenia ran psychicznych, co odpowiadałoby kolejnej, paralelnej linii. Po trzecie, pieśń chwały, תִּ odnosi się w Biblii Hebrajskiej do chwały czy sławy zarówno człowieka lub miasta (Syjonu w Iz 62,7, jego bram w Iz 60,18), jak i Boga (często pojawiająca się w wezwaniach do chwalenia Boga, wywyższania go; por. Iz 42,8.10.12; 43,21 i 48,9; 60,6 i 61,11). ${ }^{95}$ Ponieważ włączona jest do metafory szaty (por. też olej z poprzedniej linii), to chodzi o wywyższenie nie Boga, lecz żałobników, których sytuacja ulegnie diametralnej zmianie. ${ }^{96} \mathrm{Wy}-$ wyższenie to tworzy wyraźny kontrast ze „słabym duchem”, przy

91 Zob. też G. W a n k e, אעפר, w: THAT, t. II, kol. 353-356.

92 Na Triz przypada 1/5 przypadków występowania tego rdzenia w Starym Testamencie. Więcej do tego słowa J. F a b r y, שישׁשוש, w: TWAT, t. VII, kol. 721-729, zwł. kol. 722-725.

93 Do tego W. L a u, Schriftgelehrte Prophetie in Jes 56-66, s. 78 przyp. 252.

94 Zob. H. R i n g g r e n, wֶ, w: TWAT, t. VIII, kol. 252-254.

95 Zob. C. We s te r m a n n, הלל, w: THAT, t. I, kol. 493-502.

96 Tak też J.L. K o o le, Isaiah III, t. 3: Isaiah 56-66, s. 278, który zwraca uwagę, że wyrażenie to mogłoby oznaczać wykwitną, piękną szatę. Por. również C. We st e r m a n n, הלל, kol. 501. 
czym רִִּ odnosi się do witalności, ${ }^{97}$ a przymiotnik do słabości, wyczerpania sił (zob. Iz 42,3 i czasownik w 42,4)..$^{98}$ Żałobnicy czy opłakujący Syjon są jeszcze zniechęceni i zrezygnowani, pozbawieni nadziei (zob. Ez 21,12), ${ }^{99}$ ale posłaniec zapowiada odmianę ich losu.

Wiersz 3b. Skutkiem (pf. cons. w tym wierszu) takiej przemiany będzie nazywanie (ponownie קרא, ale w pu. i w znaczeniu nazywania czy oznajmiania czegoś o kimśs ${ }^{100}$ nową nazwą płaczących (po Syjonie). Za formą bierną nie stoi posłaniec, bo w w.2 włączał siebie do odbiorców, używając 1. os. pl., ani przypuszczalnie Bóg (pass. divinum), gdyż w.3b $\beta$ zdaje się mówić o Bogu w 3. os. (nie jest to pewne, jako że imię JHWH to $n$. rectum). Jest to zatem reakcja otoczenia, które w żaden sposób bliżej nie zostało określone. Ponownie odwołano się do obrazów: dęby, tj. silne i wytrzymałe drzewa (od $\boldsymbol{x}^{2}=$,siła”), ${ }^{101}$ i plantacja czy uprawa, ${ }^{102}$ która kojarzy się z żyzną ziemią i obfitą roślinnością. ${ }^{103}$ Żałobnicy staną się jak potężne, mocne dęby, które zostały opisane mianem הָרֵ (wprawdzie bardzo rzadko rzeczownik ten występuje z przedimkiem, ${ }^{104}$ ale wynika to przypuszczalnie z tego, że jest $n$. rectum - określana wielkość jest

97 J.L. K o o le, Isaiah III, t. 3: Isaiah 56-66, s. 277.

98 W. L a u, Schriftgelehrte Prophetie in Jes 56-66, s. 78, sądzi, że to jednostkowe wyrażenie powstało prawdopodobnie w nawiązaniu do 42,3 .

99 Tylko te dwa razy spotykamy zestawienie רִּ ר $\mathrm{z}$ rdzeniem כהה.

100 Zob. HAHAT. Pu. (pass. q.) też w Iz 58,12; 62,2 oraz 65,1; Ez 10,23 i w innym sensie w 48,12 (,powołany”). W.A.M. B e u k e n, The Main Theme of Trito-Isaiah “The Servants of JHWH”, JSOT 47/1990, s. 71, twierdzi, że w Triz nazywanie/ wzywanie kogoś jest zawsze tożsame z przeniesieniem do nowej egzystencji.

101 J.L. K o o 1 e, Isaiah III, t. 3: Isaiah 56-66, s. 278.

102 Zob. HAHAT. Rzeczownik pojawia się jeszcze w Iz 60,21 i dosłownym sensie w Ez 17,7; 34,4.29; Mi 1,6. O.-H. S t e c k, Jesaja 62,10-12 als Abschluß eines Großjesajabuches, w: te n ż e, Studien zu Tritojesaja, s. 148, dostrzega związek z Iz 5,7ab.

${ }^{103}$ J.L. K o o le, Isaiah III, t. 3: Isaiah 56-66, s. 278, sądzi, że zastosowana metaforyka bazuje na aliteracjach wiążących się z אבֶּ

${ }^{104}$ Cztery razy tamże, s. 279. Natomiast W.A.M. B e u k e n, The Main Theme of Trito-Isaiah “The Servants of JHWH”, s. 72, uważa, że przedimek jest znaczący, wskazując na pełną (opisowy superlatyw). 
zdeterminowana, jak w Iz 1,26). ${ }^{105}$ Trudno ustalić, w jakim sensie użyto tego rzeczownika, gdyż może oznacza zarówno właściwe, lojalne postępowanie, jak i stan z niego wynikający, tj. zbawienie czy harmonia społeczna. ${ }^{106} \mathrm{~W}$ najbliższym kontekście (w.10-11 oraz 62,1-2) pojawia się w tym drugim znaczeniu (inaczej np. w Iz 1,26, a także 64,4 ; por. też 60,21 ). Ale nie ma powodu, by nie miał łączyć w sobie obu tych znaczeń: żałobnicy doświadczą Bożego zbawienia, jak i będą sprawiedliwymi w sensie właściwej postawy życiowej. ${ }^{107}$ Paralelna plantacja JHWH pokazuje, że staną się oni jak bujnie rosnąca plantacją, która należąc do JHWH, przyczyni się do sławienia JHWH ( פרא hitp. - tak jak w Iz 44,23; 49,3; 60,21). ${ }^{108}$ Ostatecznym celem jest zatem wychwalanie JHWH przez cały świat (tutaj domyślnie, ale por. Iz 44,23 oraz 42,12; 48,11), do czego zmierza aktywność posłańca, jak i Deuteroizajaszowego sługi JHWH we współpracy z Izraelem. ${ }^{109} \mathrm{Jak}$ się wydaje, imię JHWH ustawiono w nieprzypadkowych miejscach w w.1-3: na początku (w. 1: powołanie sługi-proroka), w środku (w. 2: Boża łaska) i na końcu (koniec w. 3: Boża chwała).

W w.1-3 przemawia posłaniec-prorok, ${ }^{110}$ namaszczony do tego zdania (wątki królewskie; por. Ps 45,8; Iz 11,2), którego misję autoryzuje Bóg (powołanie, wyposażenie i wysłanie z zadaniem głoszenia i pocieszania), przy czym jego działalność zlewa się stopniowo w jedno z Bożą zbawczą aktywnością. Wiersze te nie mówią bynajmniej

${ }^{105}$ W Iz 1,26 nazwie nadanej (קרא ל) Jerozolimie. Poza tym zdeterminowany הַצב jeszcze tylko w Koh 3,16 (też jako n. rectum). A. S p a n, Die Stadtfrau Zion im Zentrum der Welt, s. 225-226, sądzi, że wyrażenie to bazuje właśnie na Iz 1,26 (zob. też dąb z 1,29).

106 Zob. K. K o c h, צדק, w: THAT, t. II, kol. 507-530.

${ }^{107} \mathrm{Ku}$ temu skłania się także J.L. K o o 1 e, Isaiah III, t. 3: Isaiah 56-66, s. 278. Jeszcze inaczej J. B l e n k i n s o p p, Isaiah 56-66, s. 226 (za P. Volzem): właściwy dąb, tj. dąb, taki, jaki powinien być.

${ }^{108}$ Poza tym hitp. tego czasownika występuje jeszcze w Sdz 7,2 (o Izraelu) i w kontekście nieteologicznym w Iz 10,15; Wj 8,5.

${ }^{109}$ Do tego szerzej H.-J. He r m i s s o n, Israel und der Gottesknecht bei Deuterojesaja, ZThK 79/1981, s. 1-24.

${ }_{110}$ Zob. W. L a u, Schriftgelehrte Prophetie in Jes 56-66, s. 67; J. B 1 e n k i n s o p p, Isaiah 56-66, s. 221. 
o powołaniu proroka, lecz co najwyżej mogą być czymś w rodzaju jego legitymizacji. ${ }^{111}$ Posłaniec do złudzenia przypomina Deuteroizajaszowego sługę Pana z Pieśni czy wręcz się z nim identyfikuje. ${ }^{112}$ Został posłany do tych, którzy opłakują stratę i Syjon, są uciśnieni, więzieni i zniechęceni, jednak ich sytuacja ulega zmianie, stając się powodem do chwalenia Boga. Powyższa analiza pokazała, że słownictwo jest częściowo łudzące podobne do Dtiz (zwracają uwagę związki z prologiem, drugą częścią Dtiz 49-55 i takimi fragmentami jak 42,5-7), a jednocześnie mamy do czynienia także z zupełnie nie-Deuteroizajaszowymi sformułowaniami.

Kolejne wiersze przynoszą konkretne obietnice, pokazując, w jaki sposób Bóg pocieszy wyzwolonych więźniów i opłakujących Syjon.

111 Zob. tamże, s. 223; a przede wszystkim W. L a u, Schriftgelehrte Prophetie in Jes 56-66, s. 72, 89: apologia proroka uczonego w Piśmie w reakcji na zastrzeżenia czytelników wobec obietnic z rozdz. 60. Apologetyczna legitymizacja może być wątkiem w.1-3, ale z pewnością nie całego rozdziału. Nie sposób też dojrzeć tutaj postulowanych przez Lau'a związków z ,prorokiem jak Mojżesz” z Pwt 18,9-22. Inne próby identyfikacji mówiącego, np. z jakąś prorocko-wizjonerską grupą Lewitów, wykraczają poza to, co można wyczytać z tekstu (tak też ocenia J. B l e n k i n s o p p, Isaiah 56-66, s. 220-221). Do tego zob. jeszcze poniżej.

112 Taka identyfikacja jest postrzegana jako oczywista, a w szczegółach nieco odmiennie rozumiana: K. K o e n e n, Ethik und Eschatologie im Tritojesajabuch, s. 105-107 - prorok, który postrzega się jako stojącego w tradycji sługi JHWH (Koenen identyfikuje go z następcą Deuteroizajasza, który był tym sługą JHWH); W. L a u, Schriftgelehrte Prophetie in Jes 56-66, s. 69-71 - autobiograficzną Tritoizajaszową interpretację ,,ja”, który identyfikował się ze sługą (jako że sługa Pana przedwcześnie zmarł - Iz 53); P.D. H a n s o n, Isaiah 40-66, Interpretation: A Bible Commentary for Teaching and Preaching, Louisville, Kentucky, s. 223-224; J. B l e n k i n s o p p, Isaiah 56-66, s. 220-223 - ostatecznie uczeń „sługi JHWH”, jednego z pośród ,sług JHWH” z Iz 65-66, którzy postrzegali siebie jako potomstwo sługi z 53,10 (por. też 59,21; tak już też W.A.M. B e u k e n, The Main Theme of Trito-Isaiah "The Servants of JHWH”, s. 72). Całkowicie odmiennie O.-H. S t e c k, Der Rachtetag in Jesaja 61,2, s. 107, przyp. 4, s. 111, przyp. 22, s. 117, przyp. 43; A. S p a n, Die Stadtfrau Zion im Zentrum der Welt, s. 210-214 - Syjon (do tego zob. powyżej). 
Wiersz 4. Rozpoczyna się on od pf. cons., a tym samym chce być kontynuacją w.3b. ${ }^{113}$ Treścią nie jest już działanie posłańca ani jego skutki, lecz Boża obietnica, mogąca być niosącym pocieszenie przesłaniem prorockim. ${ }^{114}$ Pierwszą z obietnic jest odbudowa: - por. Iz 44,26.28; 45,13 (w tych dwóch ostatnich wierszach ma to być dzieło Cyrusa; 58,12);115 60,10, w którym jest to zadanie dla cudzoziemców; ${ }^{116}$ paralelny (chiazm) ק ק w pol. (impf., co pokazuje, że odbudowa jeszcze się nie dokonała), który może podkreślać konieczność dużego nakładu siły czy zapału - por. ponownie Iz 44,26; 58,12;117 חרש pi. (ponownie na początku półwiersza pf. cons.), oznaczający odnowienie, ulepszenie w opozycji do tego, co było wcześniej (rdzeń w zwiastowaniu prorockim pojawia się tylko w okresie wygnania i po nim, przede wszystkim w Dtiz, np. 42,10; 43,19, i Triz - 62,2 i dalsze; por. też Jr 31,31; Ez 11,19; 18,31; 36,26).$^{118}$ Odnowione miasta będą miały zatem kwantytatywnie nową jakość (por. 62,2). ${ }^{119}$ Ruinami określa się w Iz 44,26; 49,19; 51,3; 52,9 Jerozolimę (por. też 5,17), ${ }^{120}$ dlatego taki sens jest najprawdopodobniejszy tutaj i w 58,12. Paralelnie ruiny te zostały nazwane spustoszeniami, ${ }^{121}$ które to słowo stoi w Iz 49,8 dla

113 Nawet C. W e s t e r m a n n, Das Buch Jesaja: Kapitel 40-66, s. 292, dzieląc rozdział na dwie perykopy (w.1-3/4-11+10), zauważa, że przejście między nimi jest płynne.

114 Zob. J.L. K o o 1 e, Isaiah III, t. 3: Isaiah 56-66, s. 279.

115 Prawie identyczne sformułowanie - do związku 61,(1-) 4 z 58,12 zob. poniżej.

116 C. We s t e r m a n n, Das Buch Jesaja: Kapitel 40-66, s. 294, uważa, że czasownik ten wyjątkowo często pojawia się w Triz (jeszcze 65,21-22 [w komentarzu omyłkowo 65,23]; 66,1), co świadczy ma o tym, że Tritoizajaszowi chodzi głównie o odbudowę.

${ }_{117}$ Zob. K. E 11 i g e r, Deuterojesaja, s. 473; A. Samuel, 마, w: THAT, t. II, kol. 635-641, tutaj kol. 637. Pol. tylko cztery razy w Biblii Hebrajskiej.

118 Zob. C. W e s t e r m a n n, חדש,, w: THAT, t. I, kol. 524-530.

119 Tak też J.L. K o o 1 e, Isaiah III, t. 3: Isaiah 56-66, s. 280.

${ }^{120}$ Poza tym jeszcze w Iz 48,21, w aluzji do exodusu (pustynia i ziszczone obszary - H.-J. H e r m i s s o n, Deuterojesaja, cz. 2: Jesaja 45,8 - 49,13, s. 305); 64,10 dla świątyni i tak jak tutaj w 58,12.

${ }^{121}$ Od rdzenia שמם, którego sens obejmuje zarówno bycie spustoszonym, w ruinie (obiektywnie), jak i czucie się pozbawionym życia, zdrętwiałym, przerażonym 
kraju, a w najbliższym rzeczowo Iz 49,19 obok ruin i zniszczonego kraju. ${ }^{122} \mathrm{~W}$ kolejnej linii spojrzenie rozszerza się na miasta, leżące w ruinach (w.4b). ${ }^{123} \mathrm{~W}$ Iz 40,9; 44,26 natrafiamy na miasta judzkie, a 64,10 „miasta święte” powiązane z Jerozolimą. Posłaniec ma więc na uwadze Jerozolimę oraz leżące wokół niej miasta i kraj, jej bliższe i być może dalsze otoczenie. ${ }^{124}$

Trudniejsze w interpretacji są dołączone określenia czasowe. עוֹלם może oznaczać bardzo długi czy odległy czas zarówno w przeszłości, jak i przyszłości. ${ }^{125}$ Mógłby oznaczać, że Jerozolima i miasta od bardzo dawna leżą w ruinie (por. deuteroizajaszowe mowy sądowe Iz 42,14; 44,7; 46,9; też 57,11). ${ }^{126}$ Jednak zarówno w Dtiz (Iz 40,8; 45,17; 51,6.8 itd.), jak i w Triz (Iz 61,7-8; 60,15.19-20; 59,21 itd.) „wieczność” często odnosi się do przyszłego czasu zbawienia, i to takiego, który już nie przeminie. Wyrażenie חרבוֹת עוֹלם poza 58,12 pojawia się jeszcze tylko w Jr 25,9; 49,13, gdzie mowa jest o unicestwieniu na wieki wrogów Izraela. Prawdopodobnie nie chodzi więc tutaj o „prastare ruiny”, lecz o odbudowę ruin na wieki (acc. przysłówkowy). ${ }^{127}$

(subiektywnie, co może być też reakcją na nieszczęście kogoś innego). Analogiczne znaczenie mają wyprowadzone z niego rzeczowniki; F. S t o l z, שמם, w: THAT, t. II, kol. 970-974.

${ }^{122}$ Por. też inne formy w Iz 54,1 dla dzieci Syjonu, w 54,3 dla miast otaczających Jerozolimę

${ }^{123}$ חיר $^{2}$ jeszcze w Jr 49,13; 50,38; Ez 29,10 (?); So 2,14 (uszkodzony?) - HAHAT.

${ }^{124}$ Por. J.L. K o o l e, Isaiah III, t. 3: Isaiah 56-66, s. 152, który twierdzi, że przede wszystkim mowa jest wprawdzie o Syjonie, to jednak jako centrum całego kraju.

${ }^{125}$ Zob. E. J e n n i, עוֹלם, w: THAT, t. II, kol. 228-243, zwł. 230,235,239-240, który sądzi, że termin ten służył Dt- i Triz do wskazania na ostateczność nieszczęścia lub zbawienia.

126 Tak W. L a u, Schriftgelehrte Prophetie in Jes 56-66, s. 80, który sądzi, że tekst powstał tak późno, że zniszczenie Jerozolimy należy do zamierzchłej przeszłości, a określenia w tym wierszu są historycznie konkretne; J. B l e n k i n s o p p, Isaiah 56-66, s. 226 (z perspektywy połowy V w.); zaś L. Stachowiak, Ksiega Izajasza $I I-I I I$, s. 285, twierdzi nawet, że mowa jest o ruinach nie tylko z czasów inwazji Nebukanesara, ale i wcześniejszych.

${ }^{127} \mathrm{~W}$ podobną stronę zmierza interpretacja w J.L. K o o l e, Isaiah III, t. 3: Isaiah $56-66$, s. 152. 


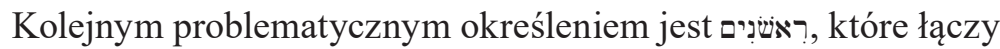
z rzeczownikiem fem., tak że nie może być raczej rozumiane przymiotnikowo. Forma pl. masc. (zawsze bez przedimka) pojawia się jeszcze w Kpł 26,25 (wraz z rzeczownikiem fem. בְּרִית) oraz Pwt 19,14; Ps 79,8, odnosząc się do praojców, przodków. ${ }^{128}$ Można więc wnioskować, że mowa jest o zniszczeniach, które miały miejsca w czasach przodków, wcześniejszych pokoleń. ${ }^{129}$ Trzecim czaso-

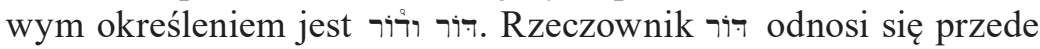
wszystkim do trwania czy kontinuum, przy czym nie jako wielkości abstrakcyjnej, lecz mierzonej długością ludzkiego życia, tj. następstwa kolejnych pokoleń. ${ }^{130}$ Utrwalona formuła ריוֹר ודרוֹר, która ponad 30 razy pojawia się w Starym Testamencie, oznacza ,zawsze"131 w przeszłości (np. Pwt 32,7) bądź przyszłości (np. Iz 60,15). ${ }^{132} \mathrm{~W}$ Triz pojawia się w podobnym sformułowaniu w Iz 58,12 oraz w 60,15 dla wiecznej, nadchodzącej, przyszłej radości (podobnie Iz 51,8). Jest więc paralelnym pojęciem do עוֹל razem z którym tworzy klamrę, obramowanie kompozycyjne tego wiersza, odnosząc się do ostatecznego, wiecznego odnowienia spustoszonej Jerozolimy i miast (judzkich). ${ }^{133}$

Pozostaje jeszcze pytanie, kto ma odbudować Jerozolimę oraz miasta. W grę wchodzą: ci, którzy w w.3b nazywani zostali „dębami

${ }^{128}$ Poza tym w Biblii Hebrajskiej jeszcze tylko w Pwt 4,32, gdzie mowa jest o dawnych dniach.

${ }^{129}$ Zob. J.L. K o o 1 e, Isaiah III, t. 3: Isaiah 56-66, s. 281, zaznaczając, że w Ps 79,8 nie ma charakteru czasowego, ale stoi w ramach opozycji pomiędzy przodkami a sprawiedliwymi. Liczebnik ten w różnych formach - poza pl. masc. - pojawia się często w Dt- i Triz, z zasady odnosząc się do wcześniejszych czasów czy wydarzeń (np. Iz 41,22).

${ }^{130}$ Również w odniesieniu do ludzi żyjący w obecnym czasie, jak w Iz 53,8.

131 Zob. G. G e r l e m a n, דוֹ, w: THAT, t. I, kol. 443-445.

132 Zob. HAHAT.

${ }^{133}$ Tak też J.L. K o o le, Isaiah III, t. 3: Isaiah 56-66, s. 152, a inaczej HAHAT. 
sprawiedliwości"; ${ }^{134}$ obcy z w.5 i 60,$10 ;{ }^{135}$ podmiot nieokreślony. Obcy w 60,10 są budowniczymi, którzy mają odbudować mury Jerozolimy (w powiązaniu z pielgrzymką narodów na Syjon - zob. 60,3-9.13-14), zaś w w.5 pasterzami, rolnikami i pracownikami w winnicach. Wprawdzie ich udział w pracach rolnych i ogrodniczych nie wyklucza obarczenia odbudową Jerozolimy i miast, to jednak zaskakiwałoby, że nowy podmiot został podany dopiero $\mathrm{w}$ w.5. W bezpośrednim kontekście analizowanej perykopy odbudową mają się raczej zająć uwolnieni więźniowie i opłakujący Syjon, którzy staną się mocnym ludem (zbawionym i sprawiedliwym), czyli wygnańcy i rozproszeni, którzy na nowo stają się ludem Jerozolimy. ${ }^{136}$ Jeśli zaś rozdz. 60-62 miałyby stanowić całość, to byłoby to przede wszystkim zadaniem obcych. ${ }^{137}$ Natomiast przyjmując podmiot nieokreślony, pytanie pozostawałoby bez jednoznacznej odpowiedzi, ale sprowadzałoby się de facto do powyższej alternatywy. ${ }^{138}$

Należałoby też przyjrzeć się współzależności w.4 z Iz 58,12: $\mathrm{Z}$ którego $\mathrm{z}$ nich czerpał autor drugiego $\mathrm{z}$ nich? Na to pytanie nie

${ }^{134}$ Tak przede wszystkim J.L. K o o l e, Isaiah III, t. 3: Isaiah 56-66, s. 279; też K. K o e n e n, Ethik und Eschatologie im Tritojesajabuch, s. 113, który dostrzega wyraźną cezurę między w.1-4/5-6; podobnie A. S p a n, Die Stadtfrau Zion im Zentrum der Welt, s. 226-227.

${ }^{135}$ Tak W. L a u, Schriftgelehrte Prophetie in Jes 56-66, s. 79-80, według którego budowanie nie przystaje do kapłańskiej funkcji ludu, a po tym, jak Cyrus w rzeczywistości nie doprowadził do odbudowy (Triz czerpie z Iz 44,26), zadanie to przechodzi na obce narody (Iz 60,10). W jego opinii w kontekście Triz tylko obcy mogą być tymi, którzy odbudowują Jerozolimę.

136 Zob. J. B 1 e n k i n s o p p, Isaiah 56-66, s. 214: mieszkańcy Jerozolimy.

${ }^{137}$ Inaczej A. S p a n, Die Stadtfrau Zion im Zentrum der Welt, s. 227, która sądzi, że w Iz 60,10 Syjon trzeba rozumieć w wymiarze przestrzennym (konstytuowanie centralnego znaczenia Syjonu i jego otwarcie na zewnątrz), a w 61,4 w wymiarze społeczno-ekonomicznym jako koniec niesprawiedliwości w jego środku.

${ }^{138}$ Do tego ponownie J. B l e n k i n s o p p, Isaiah 56-66, s. 226, który dostrzega sprzeczność pomiędzy w.4 a 60,10, zaś „niedopuszczenie” do odbudowy obcych miałoby się wiązać z Ne 3, choć redaktor na nowo zdaje się włączać obcokrajowców. 
da się udzielić przekonującej odpowiedzi ${ }^{139}$. Faktem jest, że temat odbudowy w rozdz. 61 pojawia się jedynie w tym wierszu, stojąc między większymi częściami (w.1-3/5-6/7-9/10-11), ${ }^{140}$ przy czym w.1-3 i 10-11 oraz 5-9 są leksykalnie i rzeczowo powiązane. Z kolei 58,12 jest częścią warunkowej obietnicy z 58,9b-12 dołączonej do tzw. kazania postnego z 58,1-9a. Następna perykopa 58,13-14 zajmuje się obchodzeniem szabatu. Porzucenie wyzysku biednych i wsparcie głodnych i uciskanych (warunek w w.9b-10a) doprowadzi do rozkwitu ludu Bożego i jego zbawczej przemiany w rajski ogród pod Bożym prowadzeniem (w.10b-11). Wiersz 12 zdaje się kontynuacją tej obietnicy, ale wprowadza do niej podobnie jak 61,4 zupełnie nowy wątek.

Wiersz 5. Rozpoczyna się pf. cons., jest formalnie kontynuacją w.3b-4, ale podany został (nowy) podmiot i po raz pierwszy w rozdz. 61 pojawia się adresat w 2. pl. masc. Początkowy czasownik עמר sygnalizuje podjęcie działania, gotowość wypełnienia jakiegoś zadania. ${ }^{141}$

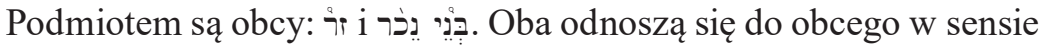
etnicznym i politycznym, tj. cudzoziemca, a w liczbie mnogiej do obcego ludu, nieraz do wrogów. זר ז ז występuje w Triz tylko tutaj

${ }^{139}$ Zob. J.L. K o o l e, Isaiah III, t. 3: Isaiah 56-66, s. 279-280. W. L a u, Schriftgelehrte Prophetie in Jes 56-66, s. 79 przyp. 258, jest przekonany, że 58,12 czerpie z 61,4, ale zakładając, że podmiotem muszą być obcy. Z kolei K. K o e n e n, Ethik und Eschatologie im Tritojesajabuch, s. 109-112, widzi w 58,3-12 (wraz z 57,14-19*) i 61,1-4 rękę tego samego autora; podobnie już wcześniej np. O. K a i s e r, Einleitung in das Alte Testament: Eine Einführung in ihre Ergebnisse und Probleme, Gütersloher Verlagshaus Gerd Mohn, Gütersloh $1975^{3}$, s. 249, który m.in. w rozdz. 61 i 58,1-12 dostrzega dzieło jednego autora, Tritoizajsza. Nieraz jednak przedstawia się Iz 56-66 jako koncentrycznie zbudowane, w którym środkowa część (rozdz. 60-62) jest najstarsza, a ramy (niekoniecznie w całości pochodzące od jednego autora) są kolejnym/i rozszerzeniem/ami; zob. W.H. S c h m i d t, Wprowadzenie do Starego Testamentu, s. 224-225; H.-W. J ü n g 1 i n g, Das Buch Jesaja, s. 444-445.

${ }^{140}$ Do tego zob. poniżej.

${ }^{141}$ Zob. J.L. K o o l e, Isaiah III, t. 3: Isaiah 56-66, s. 282. Zaś L. S t a c h o w i a k, Księga Izajasza II - III, s. 285, tłumaczy o dziwo: „zatrzymają się [tu]”.

${ }^{142}$ Choć znaczeniowo nie są do nich ograniczone, np. ำ może być określeniem

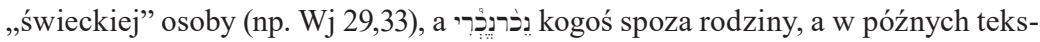
tach prozelitów (Iz 56,3.6). Oba bywają powiązane z obcymi kultami. Oba słowa 


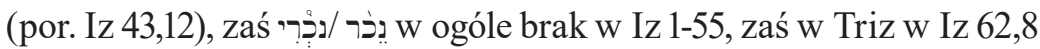
dla wrogów, a w 60,10 dla budowniczych Jerozolimy. Podobnie jak w 60,10 role ulegają odwróceniu: obcy, którzy ciemiężyli Izraelitów, staną się ich sługami, ${ }^{143}$ wykonującymi pośledniejsze prace pasterskie i polowe. Posiadaczami stad, pól i winnic są adresaci (por. Iz 60,21), a nie obcy pracownicy. Cudzoziemcy będą zaś paśli i strzegli (רעה) stad (drobne bydło - por. Iz 60,7). Będą uprawiać pola ${ }^{144}$ i winnice. ${ }^{145}$ Uprawa ziemi i winnic oraz wypas stad wskazują, że odbiorcami nie są jedynie wygnańcy, którzy na nowo zasiedlili Jerozolimę, ale także zamieszkali tereny kraju otaczającego miasto (zob. w.7), a nawet wydaje się prawdopodobne, że adresatów nie powinno się ograniczać do byłych wygnańców, ale rozszerzyć na mieszkańców Jerozolimy i kraju. ${ }^{146}$

Wiersz 6. Adresaci ci będą nazywani kapłanami JHWH (kontynuowana jest 2. os. pl.). ${ }^{147} \mathrm{Ni}$. czasowników קרא (por. w.3) społeczne uznanie, ich funkcja kapłańska zyska uznanie - w oczach narodów, jak sugeruje druga część wiersza. Chodzi więc nie tyle o ich polityczną, ile o religijną rolę. ${ }^{148}$ Najwyraźniej kapłanami będzie nazywany cały lud, a w świetle w.1-3 są to przede wszystkim wygnańcy

mają siłą rzeczy przeważnie negatywną lub obojętną konotację J. S c h r e i n e r, Stary Testament, w: J. S c h r e i n e r, R. K a m pl i n g, Bliźni / obcy/nieprzyjaciel: Z perspektywy Starego i Nowego Testamentu, tłum. J. Z y c h o w i c z, WAM, Kraków 2001, s. 48. Więcej o tych pojęciach L.A. S n ij d e r s, זרזּר, w: TWAT, t. II, kol. 556-564; B. L a n g, נכר, w: tamże, t.V, kol. 454-462; R. M a r t i n - A c h a r d, ז, w: THAT, t. I, kol. 520-522; t e n ż e, רנינ, wamże, t.II, kol. 66-68.

${ }^{143}$ Podobnie J.L. K o o 1 e, Isaiah III, t. 3: Isaiah 56-66, s. 281.

144 אָּר to rzadkie słowo, jeszcze w Am 5,16; Jr 14,4; obok pasterzy w Jr 31,24; 51,23 czy winogrodników w $2 \mathrm{Krn} 26,10 ; \mathrm{Jl} 1,11$.

${ }^{145}$ O.-H. S t e c k, Jesaja 62,10-12 als Abschluß eines Großjesajabuches, s. 148, na tej podstawie postuluje związek z Iz 5.

${ }^{146}$ C. We s t e r m a n n, Das Buch Jesaja: Kapitel 40-66, s. 124, mówi tutaj po prostu o Izraelu i Judejczykach, a J.L. K o o 1 e, Isaiah III, t. 3: Isaiah 56-66, s. 283, o odnowionym Izraelu.

${ }^{147}$ Pf. cons. z poprzedniego wiersza jest kontynuowane przez impf. Zwraca uwagę, że czasowniki stoją zawsze na końcu linii.

148 J.L. K o o 1 e, Isaiah III, t. 3: Isaiah 56-66, s. 283. 
po powrocie. Idea ta przywodzi na myśl $\mathrm{Wj} 19,6 .{ }^{149} \mathrm{Nie}$ jest to demokratyzacja czy zniesienie tradycyjnego kapłaństwa, lecz przypisanie ludowi (a więc szerzej niż w Iz 66,21) ${ }^{150}$ nowej roli posługiwania kapłańskiego względem otoczenia, dla narodów. ${ }^{151}$ Kapłani reprezentowali lud przed Bogiem, w jego imieniu składali ofiary, ale również Boga wobec ludu, nauczając go, dokonując obrzędów pojednania czy udzielając błogosławieństwa. ${ }^{152}$ Lud będzie pełnić rolę pośredników między Bogiem a obcymi narodami, a tekst nie precyzuje dokładniej, o jakie funkcje kapłańskie chodzi (w takim razie o wszystkie?). Paralelna nazwa kapłańskiego ludu to „posługujący naszego Boga”. שרת pi. w P (tzw. Dokumencie kapłańskim w Pięcioksięgu), Krn, a także w Pwt jest terminus technicus dla posługi kultowej, ${ }^{153} \mathrm{za}-$ szczytnej służby, ${ }^{154} \mathrm{JHWH}$ jest tytułowany „,naszym Bogiem”. Gdyby tytuł ten nie pojawił się już w w.2, to suf. 1. os. pl. implikowałoby

${ }^{149}$ L. R u s z k o w s k i, Volk und Gemeinde im Wandel: Eine Untersuchung zu Jesaja 56-66, FRLANT 191, Göttingen 2000, s. 25; A. S p a n, Die Stadtfrau Zion im Zentrum der Welt, s. 237-239. Zaś W. L a u, Schriftgelehrte Prophetie in Jes 56-66, s. 81, uważa, że związek z tym tekstem jest mało prawdopodobny i polega tylko na tym, że jedynie te dwa razy w Starym Testamencie pozycję taką przypisano całemu ludowi, i to względem obcych.

${ }^{150}$ Nigdy więcej rzeczownik ten nie występuje w Dt- i Triz (por. krytyka Izajaszowa w Iz 24,2; 28,7).

151 Tak J.L. K o o l e, Isaiah III, t. 3: Isaiah 56-66,, s. 283.

${ }^{152}$ Do tego W. D o m m er s h a u s e n, J. B erg ma n, H. R ing gre n, פהן, w: TWAT, t. IV, kol. 62-79, tutaj kol. 68-79; zob. też J.L. K o o l e, Isaiah III, t. 3: Isaiah 56-66, s. 283.

${ }^{153}$ Do tego czasownika C. W e s t e r m a n n, שרת, w: THAT, t. II, kol. 1019-1022. Pewna grupa miejsc zdradza być może pierwotne kultowe użycie w odniesieniu do służby dla posągu kultowego (Ez 20,32; 44,12 i 1Sm 2,11; 3,1).

${ }^{154}$ HAHAT. C. W e s t e r m a n n, Das Buch Jesaja: Kapitel 40-66, s. 294, uważa, że Judejczycy mieliby tworzyć duchową warstwę przywódczą jako kapłani, a K. K o e n e n, Ethik und Eschatologie im Tritojesajabuch, s. 113, przekonuje, że nie jest tu mowa o jakiejś reformie kultowej, lecz jedynie o tym, że wszyscy Izraelici cieszyć się będą kapłańskimi przywilejami; tak też J. B l e n k i n s o p p, Isaiah $56-66$, s. 226. 
uznanie przez cudzoziemców i narody JHWH za własnego Boga. ${ }^{155}$ Tak czy inaczej uznanie dla kapłańskiej roli całego nowego ludu Jerozolimy zakłada z pewnością również uznanie w jakimś stopniu dla Boga, którego kapłanami się stali.

Posługa kapłańska przyniesie korzyści też samym kapłanom. הַ הַיל odnosi się tutaj z pewnością do mienia, bogactwa (por. Iz 60,5.11). ${ }^{156}$ Zrozumiałe jest, że kapłani korzystali z materialnych dóbr ludu (Kpł 6,9-11; 7,30-36). ${ }^{157}$ Zaś żywienie się, korzystając z bogactwa narodów, oznacza odwrócenie dotychczasowej niedoli, gdy wrogowie jedli to, co Izraelici/Judejczycy wyhodowali na swej ziemi (zob. np. Iz 1,7; a podobna myśl w 62,8-9; 65,21-22). Kapłańskiemu ludowi przypadną nie tylko dobra materialne, ale również uznanie narodów - ذבוֹד (n, którego znaczenie obejmuje bogactwo (np. Rdz 31,1) i uznanie (np. Hi 19,9). ${ }^{158}$ Lud będzie się nim chełpić, będzie z niego dumny. Będzie więc spełniony zarówno materialnie, jak i psychicznie (społecznie). ${ }^{159}$

Wiersz 7. Zdanie rzeczownikowe na jego początku ${ }^{160}$ budzi wątpliwości tekstowe i interpretacyjne. ${ }^{161}$ Ostatecznie nie ma większego wpływu na jego interpretację, czy w pierwszej linii zachować 2 . os. pl.

155 Inaczej mają się sprawy ze służbą obcych w Iz 56,6-7, gdzie nawróceni sami służą Bogu, uczestnicząc w kulcie, czy w 60,7.10, według których będą usługiwać Izraelowi (najwyraźniej nie w kultowym sensie).

${ }^{156}$ Oznacza też siłę (w tym militarną jak w Iz 43,17), ale nigdy Bożą moc; zob. A.S. va n de r Wou d e, פָ, w: THAT, t. I, kol. 823-825, tutaj kol. 823.

${ }_{157}$ Numeracja wierszy wg BHS. Zob. J.L. Koole, Isaiah III, t. 3: Isaiah 56-66, s. 284.

${ }^{158}$ Do tego pojęcia C. W e s t e r m a n n, כבר, w: THAT, t. I, kol. 794-812, zwł. kol. 795-796.798-801. Przy czym zwraca uwagę, że w Krn i tradycjach mądrościowych często pojawia się sformułowanie ,bogactwo i chwała” (np. 1Krn 29,12; $2 \mathrm{Krn}$ 1,11-12; Prz 3,16 itp.), ale nigdy z rzeczownikiem הַירל.

${ }_{159}$ Zob. K. K o e n e n, Ethik und Eschatologie im Tritojesajabuch, s. 113 (choć inaczej tłumaczy ostatni czasownik; zob. powyższą uwagę do tekstu). Z kolei L. S t a c h ow i a k, Księga Izajasza II - III, s. 286, twierdzi przy tej okazji, że uniwersalizm Tritoizajasza nie jest wolny od myśli o supremacji Izraela.

${ }^{160} \mathrm{~W}$ wierszu tym tak jak w w.6 posłużono się wyłącznie formami osobowymi impf., które w jego drugiej części znajdują się pod koniec linii.

${ }_{161}$ Zob. powyższe uwagi do tekstu oraz J.L. K o o l e, Isaiah III, t. 3: Isaiah 56-66, s. 285-288, rozważający różne możliwości przekładu tego wiersza. 
(jak w w.5-6, za czym może przemawiać fakt, że wspominany wstyd stoi w kontraście do godności kapłańskiej i chluby z uznania obcych narodów w w.6), czy skorygować suf. tak, by przystawał do reszty tego wiersza. ${ }^{162} \mathrm{Za}$ hańbę, tj. zniszczenie i poniżenie (w aspekcie obiektywnym i subiektywnym) ${ }^{163}$ adresaci uzyskają podwójne odszkodowanie. Rzeczownik מִשְנֶ, oznacza po prostu ,to, co podwójne” (tj. ,„podwójne”, „dwojakie”, „kopia”, „drugie” itp.). ${ }^{164} \mathrm{~W}$ podwójnej wysokości płacono odszkodowanie (Rdz 43,12.15; zob. też Wj 22,3.6.8; Hi 42,10; por. Za 9,12; 1Sm 1,5), ${ }^{165}$ co dobrze pasuje także do jego użycia w trzecim półwierszu. ${ }^{166}$

W paralelnym stychu mowa jest o zniewadze - rdzeń כלם jest nieomal synonimem בֶוש 41,11; 45,16-17; 50,7; 54,4). ${ }^{168}$ Zaś rzeczownik pojawia się też w Iz 45,16; 50,6. Cała wypowiedź jest rzeczowo bliska Iz 54,3-4 (בוש i), gdzie terminy te odnoszą się do spustoszenia Jerozolimy i wygnania. ${ }^{169}$

${ }^{162}$ Można by wprawdzie w zmianie osób doszukiwać się różnych aspektów (teraźniejszość vs. przyszłość, co sugeruje J.L. K o o l e, Isaiah III, t. 3: Isaiah 56-66, s. 286-287), czy spekulować, że za suf. 2. pl. kryje się lud kapłański, a za suf. 3. pl. powracający wygnańcy, to jednak splecenie treściowe w w.7 (zob. dalej), a także fakt, że w w.5 obcy pracują na „waszej” ziemi, przeczą takim interpretacjom. Zob. też powyższą uwagę do tłumaczenia.

${ }_{163}$ Do tego słowa zob. F. S t o 1 z, בוש, w: THAT, t. I, kol. 269-272, zwł. kol. 271.

164 Zob. HAHAT.

165 Tak też J.L. K o o l e, Isaiah III, t. 3: Isaiah 56-66, s. 287. Numeracja wierszy wg BHS. Na płaszczyźnie semantycznej przywodzi na myśl Iz 40,2; zob. C. W e s t e r m a n n, Das Buch Jesaja: Kapitel 40-66, s. 294.

${ }^{166} \mathrm{~W}$ alternatywnym ujęciu TM (zob. powyższą uwagę do tłumaczenia) mowa byłaby o podwójnym wstydzie, w kontraście do którego uzyskano by podwójny udział w dziedzictwie, w ziemi.

${ }^{167}$ Zob. F. S t o 1 z, בוש, kol. 271, przy czym pierwotnie rdzeń ten miał znaczyć „zostać zranionym”; S. W a g n e r, כלם, w: TWAT, t. IV, kol. 196-208, tutaj kol. 197; J.L. K o o 1 e, Isaiah III, t. 3: Isaiah 56-66,, s. 285.

${ }_{168}$ Wg K. E 11 i g e r, Deuterojesaja, s. 143; J.L. K o o l e, Isaiah III, t. 3: Isaiah 56-66, s. 161, pierwszy z nich opisuje bardziej reakcję emocjonalną, a drugi kompromitację społeczną.

${ }^{169}$ Wg A. S p a n, Die Stadtfrau Zion im Zentrum der Welt, s. 246, w w.7 następuje aktualizacja Vorgabe z rozdz. 54. 
Wiersz $7 b$ zdaje się wskazywać, że opisują przede wszystkim sytuację wygnańców (i diaspory), ${ }^{170}$ którzy utracili swoją ziemie (co odpowiadałoby w.1-3). Zamiast doświadczania zniewagi (przyimek z początku wiersza odnosi się także do kolejnego półwiersza) będą głośno okazywać swoją radość ( רנן, który spotykamy najczęściej w kontekście kultowym, w wezwaniach do chwalenia Boga, zarówno przez ludzi, jak i stworzenie - por. też Iz 42,11; 44,23; 49,13 52,9, gdzie powodem radosnego wychwalania Boga jest Jego ocalające działanie). ${ }^{171}$ Według Dt(Iz) 54,1; 52,8-9 radować się ma Jerozolima i jej mieszkańcy (w Triz jeszcze tylko w 65,14 słudzy Boży z powodu odmiany ich niedoli). Choć czasownik ten w Biblii Hebrajskiej nigdy więcej nie łączy się z dopełnieniem w acc., to jednak najprawdopodobniej przedmiotem radosnych okrzyków jest חלק (ewentualnie jako acc. przysłówkowy dla okoliczności czy powodu, z lub dla których radośnie się wykrzykuje). ${ }^{172}$ to udział (np. łupie) albo należącą do kogoś ziemia, a czasami nagroda (Koh 2,10.21 itd.), ${ }^{173} \mathrm{~W}$ Dt- i Triz pojawia się tylko w Iz 57,6, ${ }^{174}$ a czasownik w 53,12, ${ }^{175}$ gdzie odnosi się do nagrody czy zapłaty. Podobnie i tutaj jest to nagroda lub odpłata w pozytywnym sensie (odszkodowanie) w postaci odzyskania kraju, własnej ziemi, i to w podwójnej wielkości (por. kolejny półwiersz). Wygnańcy będą się głośno cieszyć, składając Bogu dziękczynienie, z powodu końca swej udręki i odzyskania swej ziemi.

${ }^{170}$ Tak J.L. K o o l e, Isaiah III, t. 3: Isaiah 56-66, s. 285. Inaczej A. S p a n, Die Stadtfrau Zion im Zentrum der Welt, s. 244-245, która sądzi, że nie tyle mowa jest o odzyskaniu mienia przez wygnańców, ile o wyzwolenie dla tych, którzy w ojczyźnie popadli w niewolę za długi.

171 Zob. R, F i c k e r, רנן, w: THAT, t. II, kol. 781-786.

${ }^{172}$ J.L. K o o l e, Isaiah III, t. 3: Isaiah 56-66, s. 286 twierdzi, że czasownik ten jest zawsze z wyjątkiem w.7 nietranzytywny, tak że mamy tutaj do czynienia z acc. przysłówkowym. Ale por. Syr 47,10 (HAHAT)

173 Zob. H.H. S c h m i d, חלק, w: THAT, t. I, kol. 576-579, zwł. kol. 577-578.

174 Znaczenie tego wiersza jest niejasne (sprawę bardzo komplikuje początkowe wyrażenie) - por. J.L. K o o 1 e, Isaiah III, t. 3: Isaiah 56-66, s. 60. Jak sądzę, mowa jest o „nagrodzie” czy raczej odpłacie, w tym przypadku karze za bezbożność.

175 Jeszcze mający inne znaczenie ${ }^{1}$ (hi.) w Iz 41,17. 
Otwierające w.7b לכי ma zasadniczo znaczenie kauzatywne „dlatego", „z tego wynika", ${ }^{176}$ ale często uważa się, że należy go rozumieć afirmatywnie („tak”, ,z pewnością”). ${ }^{177} \mathrm{~W}$ mojej ocenie zwykłe znaczenie nie jest wykluczone, gdyż w.7b konkretyzuje formę odszkodowania i podkreśla ostateczność zbawienia. Odszkodowaniem za doświadczoną hańbę będzie (impf.) w kraju Izraela (już choćby ze względu na suf., por. np. Iz 60,18$)^{178}$ podwójna wielkość objętej w posiadanie ziemi (ירשי, którego prawie zawsze dopełnieniem jest ziemia). ${ }^{179}$ Skutkiem będzie także wieczna radość, tj. nie mająca końca w żadnym wyobrażalnym horyzoncie (por. w.4, przy czym gramatycznie i rzeczowo עוֹלם teraz bez wątpienia odnosi się do przyszłości). de terminus technicus dla głośnego, spontanicznego radosnego okrzyku, często w reakcji na doświadczone ocalenie (triumfu nad wrogami). Radość była cechą charakterystyczną świąt (kultu). Nadzieja na przyszłe zbawienie jest naznaczona radością (np. Jr 31,13; 33,11 ; Iz 51,3; 55,12; por. też 66,10). Wszystkie te aspekty radości mogą dochodzić tutaj do głosu: dziękczynna radość (wyrażana w ramach kultu?) z powodu nadchodzącego czasu zbawienia, który ma wymiar ostateczny - już nic i nigdy go nie może unicestwić. W Biblii Hebrajskiej o wiecznej radości mowa jest trzy raz, poza analizowanym wierszem jeszcze w Iz 51,11 i identycznym Iz 35,10. Wiersze te są z pewnością o siebie zależne, nie można wykluczyć, że podstawą dla sformułowań w 51,11=35,10 jest właśnie w.7. ${ }^{180}$

${ }^{176}$ HAHAT i komentarze (zob. np. J.L. K o o 1 e, Isaiah III, t. 3: Isaiah 56-66, s. 288).

177 HAHAT, s. 554, z wątpliwościami, a J.L. K o o l e, Isaiah III, t. 3: Isaiah 56-66, s. 288, podsumowująco „w tej sytuacji”, ,zatem”.

178 A nie na ziemi w sensie całego świata, tamże, s. 287.

${ }^{179}$ Często w znaczeniu „odziedziczyć”, jako że nie tylko w Izraelu, ale i poza nim wchodziło się w posiadanie ziemi przede wszystkim przez dziedziczenie - do tego czasownika H.H. Schmid, ירש, w: THAT, t. I, kol. 778-781. חלש i mogą się wywodzić z tradycji o zdobyciu kraju Kanaan, co A. S p a n, Die Stadtfrau Zion im Zentrum der Welt, s. 243, uważa za oczywiste.

${ }^{180}$ Zob. E. R u p r e c h t, שמת, w: THAT, t. II, kol. 828-835. Jeśli rację ma O.-H. S t e c k, Anschlußprobleme einer redaktionellen Entstehung von Tritojesaja, s. 279, klasyfikując Iz 51,11=35,10 do jednej z warstw ogólno-Izajaszowych 
Wiersz 8. Przynosi on uzasadnienie dla odmiany losu wygnańców i ludu z w.7, które opiera się tym, jaki jest Bóg. Posłużono się formułą samoprzedstawienia, dlatego do głosu dochodzi boskie ,ja” (najdalej od w.9b ponownie mówi się o Bogu). Formuła ta często wprowadza obietnice (np. Rdz 28,13; 15,7; Wj 6,6) i bywa związana $\mathrm{z}$ teofanią (też Wj 6,2). W Dtiz jest ważnym elementem prorockiego zwiastowania zbawienia (Iz 43,3.11.15; 44,24; 45,3 itd.,) lub podkreśla wyłączność JHWH (zwł. Iz 42,8; 45,5). ${ }^{181} \mathrm{~W}$ Triz pojawia się jeszcze w 60,16.22. W Dtiz nie tylko formuły posłańca, ale i formuły samoprzedstawienia opatrzone są często rozszerzeniami imiesłowowymi. Nie inaczej jest $\mathrm{i}$ w analizowanym wierszu (też w 60,16). ${ }^{182}$ Na rozszerzenie składają się dwa antynomiczne pojęcia. אהב, który zawsze wiąże się z praktycznym działaniem na rzecz jego przedmiotu, wyraża Boże zaangażowanie na rzecz prawości (jak w Ps

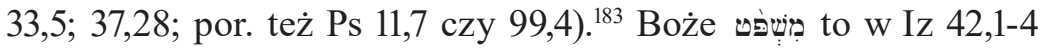
zbawczy porządek, ${ }^{184}$ a w Iz 49,4 (paralelnie do פְעִלע) ochrona prawna i zbawcza przychylność wobec sługi. ${ }^{185}$ A zatem Bóg czuwa nad za-

(Heimkehrredaktion: großjesajanisch; szerzej O.-H. S t e c k, Bereitete Heimkehr: Jesaja 35 als redaktionelle Brücke zwischen d. 1. u. d. 2. Jesaja, SBS 121, Stuttgart 1985) z przełomu okresu perskiego i helleńskiego, to sformułowania te mogłyby się opierać między innymi na 61,7.

${ }_{181}$ Zaś w Iz 42,6 mowa jest o powołującym Bogu.

${ }^{182}$ Ponieważ z pewnością natrafiamy tutaj na formułę samoprzedstawienia z rozszerzeniem, to racji nie ma J.L. K o o l e, Isaiah III, t. 3: Isaiah 56-66s. 288-289, tłumacząc jako emfazę: ,ja, JHWH jestem tym, który kocha...”.

${ }^{183}$ Zob. E. J e n n i, אהב, w: THAT, t. I, kol. 60-73, zwł. kol. 63.67.70; G. W a 1 1 i s, J. B e r g m a n, A. H a ld a r, אהב, w: TWAT, t. I, kol. 105-128, zwł. kol. 112-115. W Dtiz dopełnieniem tego czasownika są Izraelici $(43,4)$, Cyrus $(48,14)$ i Bóg $(41,8$; por. 56,6), zaś w Tr sen $(56,10)$, metaforycznie „łoża ich” $(57,8)$ i Jerozolima $(66,10)$.

${ }^{184}$ Przede wszystkim H.-J. H e r m is s o n, Israel und der Gottesknecht bei Deuterojesaja, s. 282-283; podobnie L. S t a c h o w i a k, Ksiega Izajasza II - III, s. 100;

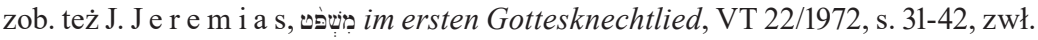
s. 35; E. H a a g, Die Botschaft vom Gottesknecht: Ein Weg zur Überwindung der Gewalt, w: N. L o h f i n k (red.), Gewalt und Gewaltlosigkeit im Alten Testament, Freiburg i in. 1983, s. 174,179-180.

${ }^{185}$ Zob. H.-J. H e r m i s s o n, Deuterojesaja, cz. 2: Jesaja 45,8 - 49,13, s. 357; J.L. K o o 1 e, Isaiah III, t. 3: Isaiah 56-66, s. 15. 
chowaniem zbawiennego porządku, naruszonego wrogością wobec Izraela, i dba o właściwe zadośćuczynienie (por. też Ps 37,28-29), ${ }^{186}$ a formułując to nieco ogólniej, przywraca równowagę naruszoną niewłaściwym postępowaniem, tj. rabunkiem. ${ }^{187}$ Bóg przeciwstawia

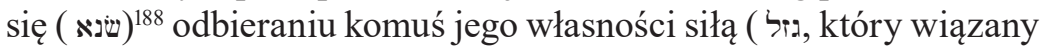
jest z przemocą i łamaniem prawa osób o niższym statusie społecznym; por. Iz 10,2). ${ }^{189}$ Wymowa rzeczownika została jeszcze wzmoc-

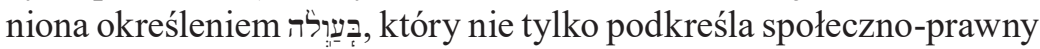
wymiar przestępstwa, ale zawsze oznacza również łamanie Bożego prawa. ${ }^{190} \mathrm{JHWH}$ aktywnie przeciwstawia się grabieniu przez obcych najeźdźców Jego ludu i kraju. ${ }^{191}$

$\mathrm{Z}$ tego wynika (pf. cons. na początku w.8b), że Bóg da ludowi (suf. nawiązujący do w.7) rekompensatę ( פְעִ jak w Iz 49,4). ności jej udzielenia opisano zwrotem zarówno faktyczność takiej rekompensaty (zob. Jr 26,17; por. też $\mathrm{z} ל$ w Iz 42,3), jak i to, że jest ona wyrazem Bożej wierności (por. Iz 10,20). W tym drugim przypadku wskazywałby w szczególności

186 J.L. K o o 1 e, Isaiah III, t. 3: Isaiah 56-66, s. 289: saving justice, powołując się na Iz 59,9.11.14; Ps 37,28. W Triz jeszcze w 56,1; 58,2; 59,8.15.

187 Tak W. L a u, Schriftgelehrte Prophetie in Jes 56-66, s. 84, który ponadto uważa, że Triz nawiązuje literacko do Mi 3,9; por. też Mi 3,2, ale trudno byłoby tego dowieść, gdyż para שנא i אהב stoi razem ponad 30 razy w Starym Testamencie.

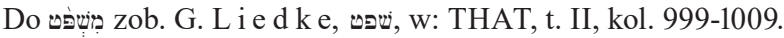

${ }^{188}$ Do tego czasownika E. J e n n i, שנא, w: THAT, t. II, kol. 835-837. W Dt- i Triz jeszcze tylko w 60,15 i 66,5 (w odmiennych kontekstach).

189 Zob. J. S c h ü p p h a u s, גז, w: TWAT, t. I, kol. 999-1001. Rzeczownik występuje jeszcze w Kpł 5,21; Ps 62,11; Ez 22,29; Syr 16,13 (HAHAT).

${ }^{190}$ R. K n i e r i m, אעור w: THAT, t. II, kol. 224-227. W Iz jeszcze tylko w 59,3 (w odniesieniu do języka).

${ }^{191}$ Wg C. W e s t e r m a n n, Das Buch Jesaja: Kapitel 40-66, s. 295, autor odwołuje się do podboju Jerozolimy, a L. S t a c h o w i a k, Księga Izajasza II - III, s. 286 - Jerozolimy i Judei (sic!).

192 Tak też J.L. K o o l e, Isaiah III, t. 3: Isaiah 56-66, s. 290; zob. już powyżej. W Iz 40,10 i 62,11, gdzie stoi z suf. odnoszącym się do JHWH, są nią sami wygnańcy. Do tego rzeczownika zob. J. V o 11 m e r, פעל, w: THAT, t. II, kol. 461-466, zwł. kol. 464-466; K.-J. I 11 m a n, פעל, w: TWAT, t. VI, kol. 697-702, zwł. kol. 701-702.

${ }^{193}$ Przysłówkowo - do tego wyrażenia HAHAT. 
na Boga jako spolegliwego i łaskawego, przychylnego swojemu ludowi. ${ }^{194}$ Bóg zawrze ( כרת) z nim przymierze wieczne (chiazm), które tutaj tak samo jak w Iz 42,6 czy 49,8 (a także 45,10 i 55,3) trzeba rozumieć jako Bożą obietnicę czy samozobowiązanie. ${ }^{195}$ Celem przymierza było zawsze życie, powodzenie, pokój. ${ }^{196}$ Przymierze to będzie trwałe, nieprzemijalne ( עוֹלם jak w w.7). ${ }^{197}$ Związki tego wiersza z Pieśniami o słudze JHWH (por. 42,1-4; 49,1-6, a także 42,5-8; 49,7-12) są wyraźne.

Wiersz 9. Choć rozpoczyna się pf. cons., chce być kontynuacją w.8b, to jednak nie natrafiamy w nim na formy 1. os., a w w.9b $\beta$ mówi się już wyraźnie o Bogu (w 3. os.). ${ }^{198}$ Obietnica dotyczy potomstwa (chiazm), odnosi się zatem do kolejnych pokoleń. Oba pojęcia

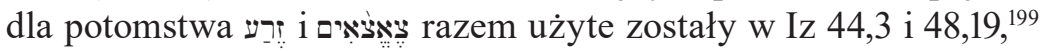
z tym pierwszym w.9 łączy również motyw błogosławieństwa. Wiele wskazuje na to, że oparto się właśnie na Iz 44,3. ${ }^{200}$ Wiersz $7 b$ mówi o odzyskaniu ziemi, a w.9 o zbawiennej przyszłości potomstwa, przez co nawiązuje się prawdopodobnie do obietnic danych patriarchom (por. Rdz 13,15-16; 26,3-4; 28,13-14; Wj 32,13). ${ }^{201}$ Ich uznanie przez

${ }^{194}$ Do אמנז H. W i 1 d b e r g e r, אמן.E, w: THAT, t. I, kol. 201-208. W tym drugim znaczeniu J.L. K o o 1 e, Isaiah III, t. 3: Isaiah 56-66, s. 290, wiążąc ten rzeczownik

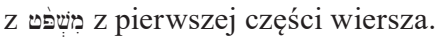

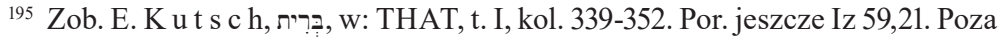
tym w Triz jedynie w znaczeniu zobowiązania „narzuconego” partnerowi, którzy musi być mu posłuszny $(56,4.6)$.

196 K. E11 i ge r, Deuterojesaja, s. 235.

197 Wyrażenie takie odnajdujemy 16 razy w Starym Testamencie, m.in. w Iz 55,3; Jr 32,40; 50,5; Ez 37,26.

${ }^{198}$ Mimo to W. L a u, Schriftgelehrte Prophetie in Jes 56-66, s. 83, uważa w.8-9 za zamykającą jednostkę mowę JHWH, podczas gdy w.10-11 mają być odrębną jednostką (przyp. 286).

199 Jeszcze w Iz 65,23. Każde z nich pojawia się w Dt- i Triz dużo częściej.

${ }^{200}$ Tak W. L a u, Schriftgelehrte Prophetie in Jes 56-66, s. 86; podobnie W.A.M. B e u k e n, The Main Theme of Trito-Isaiah "The Servants of JHWH”, s. 72-73, który w potomstwie odnajduje potomstwo sługi JHWH (por. Iz 53,10).

${ }^{201}$ Trzeba zaznaczyć, że datowanie tych tekstów jest bardzo problematyczne i sytuowane zasadniczo w czasach powygnaniowych, ale istnieją poważne powody, 
i wśród narodów (dwa paralelne określenia a a i i i 202 por. w.6) opisane zostało za pomocą trzech czasowników kognitywnych: ידע ni. wskazujący na znaczeniem potomków i ich uznanie; ראה polegający na bezpośrednim kontakcie ${ }^{203}$ - wszyscy bez wyjątku, którzy mają kontakt z potomstwem Izraela (powtórne זרֵ.), uznają je (rkn hi.)204 za pobłogosławione przez JHWH, tj. obdarzony zbawienną mocą. Bóg obdarzył siłą życiową, ${ }^{205}$ dużą liczebnością i powodzeniem potomstwo swego ludu, z czego zdadzą sobie sprawę narody, a tym samym uznają lud Boży, a pośrednio i samego Boga (por. Rdz 12,2-3). Objęcie na nowo ziemi i stanie się znaczącym narodem, a przez to świadectwem dla narodów, jest wyobrażeniem nawiązującym do Dtiz (zob. Iz 44,23; 49,5-6; por. też 43,10-12; 52,10 oraz $\operatorname{Tr[Iz]~61,6a).~}{ }^{206}$ Na końcu tej części (w.7-9) stoi imię JHWH, które powraca od razu w w.10 wraz z prorockim ,ja".

Wiersze 10-11. Tworzą one razem z w.1-3 klamrę kompozycyjną czy obramowanie perykopy. ${ }^{207} \mathrm{~W}$ tych końcowych wierszach pojawiają

by przynajmniej Rdz 28,13-14 datować na okres poprzedzający czasy powygnaniowe (zob. H. S e e b a s s, Genesis II: Vätergeschichte II (23,1-36,43), Neukirchen-Vlyun 1999, s. 321-322).

${ }^{202}$ Pierwszy z nich wskazuje bardziej na wymiar polityczny i terytorialny, zaś drugi na więzy krwi - A.R. H u 1 s t, גירֵים, w: THAT, t. II, kol. 290-325, tutaj kol. 315-316.

${ }^{203}$ Zob. D. V e t t e r, ראה, w: tamże, kol. 692-701, tutaj kol. 693-694. J.L. K o o le, Isaiah III, t. 3: Isaiah 56-66, s. 291, zwraca uwagę, że te dwa czasowniki przeważnie stoją w odwrotnej kolejności.

${ }^{204}$ Możliwe są inne znaczenia: „troszczyć się”, ,odróżniać” (por. Ezd 3,13; zob. HAHAT).

${ }^{205}$ Do tego czasownika zob. C.-A. K e 11 e r, G. W e h m e i e r, ברך, w: THAT, t. I, kol. 353-376. Czasownik ten pojawia się w (Dt)Iz 51,2 w kontekście licznego potomstwa (rozmnożenie się Abrahama i Sary w wielki lud), a w Triz m.in. w językowo powiązanym wierszu 65,23.

${ }^{206}$ M.in. C. W e s t e r m a n n, Das Buch Jesaja: Kapitel 40-66, s. 295, stwierdza, że 61,7-9 wyraźne nawiązują do zwiastowania Deuteroizajasza.

${ }^{207}$ Zob. J.L. K o o le, Isaiah III, t. 3: Isaiah 56-66,s. 292-293, który słusznie odrzuca interpretację, według której miałoby chodzić o dziękczynienie ludu (czy Syjonu-Jerozolimy, jak chcieliby A. S p a n, Die Stadtfrau Zion im Zentrum der Welt, s. 253 czy J. B 1 e n k i n s o p p, Isaiah 56-66, s. 230n, przywołujący metaforykę z Iz 
się słowa i motywy z poprzednich wierszy. Posłańca napawa wielka radość (inf. emfatyczny; שוש Zuל ביל związany jest przede wszystkim z kultowym wychwalaniem Boga (podobnie jak inne terminy dla radości). Wyraża nie tyle emocje, ile głośne okazywanie w społeczności radości. ${ }^{209}$ Ponieważ posłużono się aż trzema czasownikami dla radości, to możemy mieć do z czymś w rodzaju (opisowego) superlatywu. ${ }^{210}$ Posłaniec ( גַęę) dziękując, raduje się dzięki i w JHWH (najbliższą paralelą jest Ps 35,$9 ;^{212}$ por. też Iz 41,16), którego nazywa „moim Bogiem”, co podkreśla jego bliską, osobistą relację z Bogiem.

Uzasadnienie radości (w.10b) zostało sformułowane za pomocą obrazów ubrania ${ }^{213}$ i wierzchniego okrycia (מְעִ to płaszcz bez

62,3-5 i T: choć stworzył je prorok, to mówiącą jest Jerozolima) za doświadczone ocalenie. Zaś C. W e s t e r m a n n, Das Buch Jesaja: Kapitel 40-66, s. 295, przesuwając w.11 na koniec perykopy (wbrew temu słusznie W. L a u, Schriftgelehrte Prophetie in Jes 56-66, s. 87 przyp. 306), widzi w nim małą jednostkę (odrębna też wg tamże, s. 86-87), psalm jednostki, odpowiadający Deuteroizajaszowym hymnom, responsorium zboru przyjmującego zwiastowanie zbawienia. Zaznaczyć należy, że formalnie nie mamy tutaj do czynieni z hymnem, gdyż brak jest wezwania w impt. do chwalenia Boga, a raczej z dziękczynieniem (jednostki) (podobnie J.L. K o o l e, Isaiah III, t. 3: Isaiah 56-66, s. 267), nawet jeśli mogłoby być wypowiadane przez zgromadzenie.

${ }^{208}$ Rzeczownik od tego rdzenia w w.3 (zob. powyżej), czasownik również typowy dla Triz (np. Iz 65,18-19; 66,10 - tam wraz z lyg), a nieobecny w Dtiz.

${ }^{209}$ Do tego czasownika C. W e s t e r m a n n, גיל THAT I, kol. 415-418.

${ }^{210}$ Zob. J.L. K o o l e, Isaiah III, t. 3: Isaiah 56-66, s. 293, który dostrzega tutaj klimaks.

211 נֶֶֶׁ to określenie osoby ludzkiej z jej myślami, wolą czy emocjami, de facto tożsame z zaimkiem osobowym, co nie oznacza, że zaimkowy sens daje się odróżniać od jego „,pełnej wartości”, jak chciałby J.L. Koole, zob. tamże, s. 293.

${ }^{212} \mathrm{Wg}$ A. S p a n, Die Stadtfrau Zion im Zentrum der Welt, s. 254-255, redaktor w.10 cytuje Ps 35,9, ale rację ma W. L a u, Schriftgelehrte Prophetie in Jes 56-66, s. 88 , że nie może być mowy o cytacie, gdyż sformułowania nie są aż tak wyjątkowe, a język jest charakterystyczny dla wielu hymnów w Psałterzu.

${ }^{213}$ Ubranie było konieczne do życia (Hi 37,17). Podobny obraz spotykamy w Iz 59,17 - zob. tamże, który zasadnie twierdzi, że Iz 61,10 było podstawą dla autora 59,17 . 
rękawów, narzuta noszona przez znaczące osoby, np. kapłanów w Wj 28,4 czy Hioba w 1,20). ${ }^{214}$ Zbawienie i sprawiedliwość (por. np. Ps 132,16.9) są posłańcowi tak bliskie i z nim związane jak własne ubrania. יִשַׁ oznacza ocalające wsparcie (por. Iz 43,12), wienny porządek czy powodzenie wynikające z Bożej przychylności (zob. powyżej w.3; też por. Iz 45,18; 51,6.8). Są to dary Boga troszczącego się o posłańca (por. Iz 52,1). ${ }^{216}$ Do metafor ubrania dochodzą jeszcze porównania ( כ) do pana młodego z zawojem na głowie (por. w.3) i panny młodej przyozdobionej (ערה (24) odświętnymi szatami czy raczej biżuterią (zob. כִִִּ np. w Rdz 24,53 czy Wj 3,22). ${ }^{218}$ Wiele wskazuje na to, że porównanie z panem młodym połączone jest $\mathrm{z}$ innym wyobrażeniem (mieszana metafora) ${ }^{219}$ - pełnieniem posługi kapłańskiej ( כהן pi.). Posłaniec przyrównuje swoją radość z doświadczanego i - jeśli czytać te wiersze razem z w.1-3: głoszonego - Bożego zbawienia do pana młodego noszącego zawój tak samo jak kapłan pełniący swoją służbę. Zbawcza łaskawość Boga jest mu bliska ,jak koszula ciału" i obnosi się z nią jak z ozdobami podkreślającymi

${ }^{214}$ Zob. J. G a m b e r o n i, לבש, w: TWAT, t. IV, kol. 471-483, tutaj kol. 475-476 i 478-479; a E. J e n n i, לבש, w: THAT, t. I, kol. 867-870, tutaj kol. 869, zauważa, że dla dzisiejszego odbiorcy zaskakująco szerokie jest stosowanie przenośnych wyobrażeń z czasownikiem לבש. J.L. K o o le, Isaiah III, t. 3: Isaiah 56-66, s. 293, odnosi użyte tu rzeczowniki do „spodnich” i „wierzchnich” ubrań, co jest nie do utrzymania (por. np. $1 \mathrm{Krl} 1,1)$.

215 Zob. F. S t o 1 z, יעש hi., w: THAT, t. I, kol. 785-790.

${ }^{216}$ Dla A. S p a n, Die Stadtfrau Zion im Zentrum der Welt, s. 256, nawiązanie do Iz 52,1 uchodzi za pewne.

217 Tranzytywnie w Ez 16,11.13 czy nietranzytywnie w Oz 2,15; Jr 31,4, a obiektami mogą być m.in. klejnoty, złoto i srebro. Do nieraz postulowanego związku z Iz 49,18 (zob. też tamże, s. 258) zob. W. L a u, Schriftgelehrte Prophetie in Jes 56-66, s. 86-87.

${ }^{218}$ Zob. J.L. K o o 1 e, Isaiah III, t. 3: Isaiah 56-66, s. 294. Do obu możliwości H. M a d 1, ערה, w: TWAT, t. V, kol. 1074-1079, tutaj kol. 1075. Rzeczownik ma szerokie znaczenie,zob. K.-M. B e y s e, w: tamże, t. IV, kol. 179-185, zwł. kol. 180-184.

${ }^{219}$ Zob. powyższa uwaga do tłumaczenia. Przy czym wymowa tego porównania niewiele by się zmieniała, gdyby czasownik כהן był jednak wynikiem błędu tekstowego. 
status i godność. Dziękczynna radość i Boże zbawienia są nierozłącznie związane z misją posłańca, która daje radość i poczucie triumfu samemu posłańcowi.

Wiersz 11. Kolejne w tym rozdziale uzasadnienie pokazuje, że powodem radości posłańca jest zbawienie, które nastaje niejako samo $\mathrm{z}$ siebie. ${ }^{220}$ Tym razem posłużono się metaforą wegetacji. Ziemia sprawia (יצ hi.; por. np. Rdz 1,12 czy Iz 11,1), że wyrastają z niej rośliny (pędy, צֵֶ), a w ogrodzie (rzadka forma fem., być może dla ogrodów, które uprawiane czy doglądane były z troską; por. Iz 1,29-30; 66,3.17) ${ }^{221}$ puszczają pędy (צי, por. Rdz 3,18), zasiane rośliny. זִּוּ: tj. to, co zostało posiane (jeszcze tylko w Kpł 11,37), זִ זרע z w.9, a także ,plantacją" i drzewami z w.3, tak samo jak acy hi. z również z w. 9. ${ }^{223}$ Ogród jako miejsce spotkania kochanków (Pnp 5,1; $6,11 ; 8,13)$ może być wyobrażeniowo związany z panem i panną młodą $\mathrm{z}$ poprzedniego wiersza (jako miejsce skonsumowania ich związku). ${ }^{224}$ Jak ziemia i ogród, tak samo JHWH (do Adonaj JHWH zob. w.1) obdarza zbawieniem - צִדרקדה (tak samo jak w Iz 45,8). ${ }^{225} \mathrm{z}$ pewnością w takim sensie jak w w.10, co podkreśla też bezpośredni związek obu wierszy i użytych w nich metafor. ${ }^{226}$ Tym razem jako paralelny (chiazm) dar wymieniana jest תִּלה znana już z w. 3 (gdzie pojawia się w metaforze ubrania), w którym jest wynikiem przywrócenia pozycji wygnańców, Syjonu i jego mieszkańców, ich rehabilitacji (por. też Iz 62,7 czy 60,18). Pieśń pochwalna rozbrzmiewa wobec (do

${ }^{220}$ Tak też J.L. K o o 1 e, Isaiah III, t. 3: Isaiah 56-66, s. 295 i in.

${ }^{221}$ M.in. jako miejsce bałwochwalczych kultów. Do tego rzeczownika zob. tamże, s. 295.

${ }^{222}$ A w pl. „rośliny” - HAHAT.

${ }^{223} \mathrm{Na}$ te powiązania wskazuje C. W e s t e r m a n n, Das Buch Jesaja: Kapitel 40-66, s. 295; J.L. K o o le, Isaiah III, t. 3: Isaiah 56-66, s. 295.

${ }^{224}$ Tak tamże, s. 295.

${ }^{225}$ Wiersz ten był najprawdopodobniej literackim Vorlage dla Triz - W. L a u, Schriftgelehrte Prophetie in Jes 56-66, s. 89. Czasownik występuje także w Iz 42,9; 43,19; 44,4 (w odniesieniu do potomstwa) czy 55,10;58,8.

${ }^{226}$ Tak słusznie J.L. K o o l e, Isaiah III, t. 3: Isaiah 56-66, s. 295-296, zaprzeczając przy tym C. W e s t e r m a n n o w i (Das Buch Jesaja: Kapitel 40-66, s. 295), który widzi w w.10 odrębną jednostkę. 
pִגֵ por. Iz 40,17227 czy 49,16; 59,12) narodów, co ponownie przywodzi na myśl w.9 (a także w.6b). Taki sposób argumentacji wpisuje się w koncepcję Dtiz (zob. powyżej do w.9) - z tą różnicą, że lud staje się nie tyle świadkiem JHWH, ile jego kapłanem (w.6). ${ }^{228}$

\section{Budowa perykopy i jej interpretacja}

Perykopa jest złożona treściowo, a jej ogólną budowę można by przedstawić następująco:

- w.1-3: misja posłańca Bożego (,ja” posłańca)

- w.1-2a: wyposażenie duchem - namaszczenie i posłanie (formy osobowe) oraz zadanie głoszenia (trzy inf. czasowników dla głoszenia):

- w.1b: wyzwolenia więźniom

- w.2a: łaski i zemsty Bożej

- 2b-3: działanie posłańca i Boga wobec opłakujących Syjon prezentacja misji posłańca obramowana jest przez w.la (wyposażenie duchem) i w.3b (mocny lud, przez który Bóg się wsławia; zob. też występowanie imienia JHWH)

- w.4: odbudowa Jerozolimy i okolicznych miast

- w.5-6: służba narodów i kapłaństwo ludu (adresaci „wy” i słowa wypowiadane w ,naszym” imieniu)

- w.5: praca narodów (rolnictwo) dla „was”

- w.6a: mieszkańcy Jerozolimy/lud kapłanami JHWH

- w.6b: bogactwo i chwała narodów dla „was”

- w.7-9: odszkodowanie i uznanie potomków wśród narodów

- w.7: odszkodowanie i radość (w miejsce hańby)

${ }^{227}$ J.L. K o o 1 e, Isaiah III, t. 3: Isaiah 56-66, s. 296, rozumie נגֶר jako wskazanie na czyiś osąd stanu rzeczy.

${ }^{228}$ Czemu zaprzecza K. K o e n e n, Ethik und Eschatologie im Tritojesajabuch, s. 113. W.A.M. B e u k e n, The Main Theme of Trito-Isaiah "The Servants of JHWH”, s. 71-74, twierdzi, że mówiący w rozdz. 61 wykonuje dzieło sługi JHWH, ale jednocześnie przenosi cechy sługi na swoje audytorium, upodabnia audytorium do sługi i siebie samego. 
- w.8: Bóg i jego dar - odszkodowanie i przymierze (,,ja” JHWH)

- w.9: uznanie potomstwa przez narody (za błogosławione przez JHWH) - wiersz ten łączy z w.5-6 temat stosunku narodów do ludu Bożego, przez co może też tworzyć z tymi wierszami obramowanie w.7-8

- w.10-11: dziękczynna radość posłańca w JHWH z powodu zbawienia (,ja” posłańca)

- w.10a $\alpha$ : zawdzięczane JHWH, z dwoma uzasadnieniami i trzema obrazami

- w.10aß: szaty zbawienia

- w.10b: porównanie do pana i panny młodej (radość ze zbawienia)

- w.11: obraz wegetacji dla Bożego zbawienia (w.1lb: działanie JHWH, którego celem wychwalanie Go przez narody).

Jak można zauważyć, tekst składa się z kilku powiązanych części, a całość otaczają (zob. ramowa pozycja zwrotu אִדני יהוה) mowy posłańca w 1. os., który otrzymuje zadanie zwiastowania i pocieszania (w.1-3), a na końcu wyraża dziękczynną radość z powodu Bożego zbawienia. W środkowej części stosunek narodów i do narodów odgrywa ważną rolę. Składa się ona $\mathrm{z}$ dwóch ramowo skonstruowanych części (w.5-6 i 7-9). W pierwszej w centrum stoi kapłaństwo ludu Jerozolimy, któremu będą usługiwać narody (swoją pracą i bogactwem). W drugiej posiadanie kraju i nieustającej radości oraz stanie się znacznym ludem uznanym narody, co znajduje swoje uzasadnienie w środku tej części w charakterze Boga (Boże „Ja”), który obdarza przymierzem. Formalnie oderwany od reszty wydaje się w.4, ale rzeczowo odbudowa wiąże się z pocieszeniem (opłakujących Syjon), a gramatycznie (pf. cons.) trzeba łączyć z w.3b.229

229 Jeśli miałby powstać na podstawie Iz 60,10, to byłby treściowo mocniej powiązany z w.5 (zob. powyżej). Podobnie tekst dzieli K. K o e n e n, Ethik und Eschatologie im Tritojesajabuch, s. 103,105,112,115,119, który wydziela następujące jednostki (sic!): w.1-4/5-6/7-9/10-11, dostrzegając również powiązania między nimi (w.5-6 pomyślane jako kontynuacja w.4; w.7-9 opisują następstwa Bożego zbawienia; 
Perykopa jest zatem w miarę spójną całością, obramowaną przez w.1-3 i 10-11, które łączy nie tylko ,ja” posłańca-proroka, ale również metaforyka ubrania. Jednostkę spaja motyw uznania ze strony narodów i chwały adresatów obietnicy, którzy są też odbiorcami słów sługi (wyraźnie w w.3.5-6.7+9.11). Jeśli czytać rozdział jako całość, to są nimi wygnańcy (i rozporoszony po świecie lud), którzy powrócili i powrócą, stając się ludem Jerozolimy i otaczającego ją kraju. Zostaną oni pocieszeni i podniesieni na duchu przez posłańca (w.1-3), staną się kapłanami wobec narodów, które staną się najemnikami. Lud korzystać będzie z dóbr narodów (w.5-6). Dostaną od Boga, który nienawidzi rabunku, odszkodowanie w podwójnej wielkości: ziemię i potomstwo, które zostanie uznane przez narody, a także nieustającą radość i przymierze Bożej przychylności (w.7-9 i 11). Posłaniec rozraduje się i złoży dziękczynienie Bogu z powodu Bożego zbawienia. Ponieważ kraj ten był zrujnowany, nie może dziwić obecność kwestii podniesienia z ruin Jerozolimy i miast (w.4), nawet jeśli nie do końca wiadomo, kto tego ma dokonać. Posłaniec mówi o swoim (w.10) i „naszym” Bogu (w.2.6), obiekt jego misji staje się też adresatem (w.5-6). Centralnie umieszczono mowę JHWH (w.8): z Bożego charakteru wypływa Boża obietnica.

Cała perykopa skoncentrowana jest na zbaw c z y m d zi a ła n i u J H W H. Wspomina się wprawdzie dzień Bożej zemsty (w.2a), który jednak nie odnajduje żadnego odzwierciedlenia w całym tekście. O negatywnym Bożym działaniu mowa jest tylko w ramach antytezy (nienawidzi grabieży; w.8), w której nacisk położono na ocalającą Bożę aktywność. O d b i o r c y/a d re s a c i nie spotykają

w.10-11 to hymn Syjonu jako reakcja na obietnice zbawienia z poprzednich wierszy). Inaczej dzieli tekst W. L a u, Schriftgelehrte Prophetie in Jes 56-66, s. 66,79, który uważa w.4-7 za całość, w której obcy stoją wobec zbawionej społeczności (podmiotem w.4 muszą być obcy, jak w 60,10), uważając jednocześnie w.8-9 i 10-11 za małe jednostki (83 przyp. 286 i 86-87). Przeważnie najmocniejszą cezurę odnajduje się między w.3/4 ( C. W e s t e r m a n n, Das Buch Jesaja: Kapitel 40-66, s. 292-293), choć powiązane, a przejście między nimi jest płynne. Zaś wg J. B l e n k i n s o p p, Isaiah 56-66, s. 222.228, rozdział rozpada się na dwie perykopy w.1-7 i w.8-11 (przejście od mowy sługi do mowy JHWH), a drugą dzieli na mowę JHWH i hymn. 
się z krytyką swego postępowania: ${ }^{230}$ są oni rozbici wewnętrznie, zniechęceni, opłakują straty (Syjon) i zrozpaczeni (por. brak radości), są uciśnieni i więzieni (w.1-3; chociaż znaczenie więzienia nie jest w pełni jasne, podobnie zresztą jak w Iz 42,7), zhańbieni (w.7a), pozbawieni swego mienia i ograbieni (w.7b.8), być może pozbawieni swoich praw (por. w.8a i 1), a ponadto Syjon i miasta judzkie leżą w gruzach (w.4). Jednak ich los się odmieni: uwolnienie (w.1), pocieszenie (w.2b), radość i godność (w.3a.6b-7), uznanie otoczenia i narodów (w.3b.6b, dla potomstwa w w.9) i ich posługiwanie (w.5 i być może w.4), wieczne, tj. nieprzemijające zbawienie (w.8: przymierze, w.7.11), odbudowa ruin (w.4), korzystanie z bogactwa narodów (w.6b), potomstwo (w.9), dziedzictwo (w.7b), last but not least posługiwanie jako Boży kapłani (pośrednictwo między narodami i Bogiem, a więc już nie tylko świadectwo wobec narodów z Dtiz). $\mathrm{N}$ a ro d y nie są wielkością negatywną, nawet jeśli za hańbą, ruinami, uciskiem, rabunkiem mogą stać właśnie one. Z ich pracy (w.4[?]-5), mienia (w.6b), a przede wszystkim uznania lud Boży będzie korzystał. Jednak ich postawa sugeruje również uznanie Boga JHWH (,nazywanie” z w.3b i 6a), tak że zbawienie ludu i wygnańców (i Syjonu) oraz wychwalanie Boga (w.3ab i 1lb) będzie świadectwem o Bogu wobec narodów, dla których lud stanie się Bożymi kapłanami. W tym wszystkim ważną rolę odgrywa p o s ł a n i e c, który wyposażony i posłany przez Boga (w.1-3), by głosić zbawienie (w.2a i w.4-9) i który sam z tego powodu składa Bogu radosne dziękczynienie (w.10-11). Zbawcze oczekiwania związane są z życiem w swym kraju (po powrocie). Przesłanie jest bliskie koncepcyjnie Dtiz, zwł. rozdz. 49-55: dominuje kwestia uwolnienia, powrotu, ponownego zaludnienia Syjonu i jego powodzenia $^{231}$ - na oczach narodów lub dzięki ich służbie; i dwóm pierwszym Pieśniom o słudze Pana.

${ }^{230}$ Inaczej w mojej ocenie niesłusznie J.L. K o o l e, Isaiah III, t. 3: Isaiah 56-66, s. 290 .

${ }^{231}$ Szczegóły zob. powyższy komentarz i jeszcze poniżej. 


\section{Problemy literackokrytyczne}

W celu interpretacji tego fragmentu ważną rolę odgrywa odpowiedź na pytanie: Czy należy go odczytywać w powiązaniu z sąsiednim rozdz. 60 (i 62)? Od tego zależy nie tylko datowanie, ale i uściślenie, kim są adresaci i odbiorcy Bożej obietnicy, a także np. to, kto ma odbudować miasta (zob. powyżej do w.4). Poprzedni rozdział jest słowem JHWH (por. 60,16), mimo że mówi się o nim też w 3. os. (60,19-20) skierowanym do Jerozolimy (w 2. os. sg.) - jest zapowiedzią rozpoczynającego się zbawienia Jerozolimy, do której przybyła światłość chwały JHWH, a za nią narody, które oddadzą jej swe skarby, przyprowadzą rozproszone dzieci Syjonu i będą służyć Jerozolimie i ją odbudują. Koncentruje się na pielgrzymce narodów na Syjon, ${ }^{232}$ który będzie jaśniał Bożą chwałą, a zamieszkiwać ją będzie lud sprawiedliwy. Z kolei w 61,1 (oraz w w.10) do głosu dochodzi posłaniec Boży w 1. os., który ma ogłosić wyzwolenie jeńcom i pocieszenie opłakującym Syjon. Dopiero w w.8 pojawia się na krótko Boże ,ja”. Adresatem jest grupa (2. os. pl. w w.5-6). ${ }^{233}$ Mocno powiązane $\mathrm{z}$ rozdz. 61 wiersze $60,20 \mathrm{~b} \beta$ -22 zdają się wtórnie spajać oba rozdziały: stoją one po w.1-3 i 19$-20[\mathrm{~b} \alpha]$ z motywem Bożej chwały jako światła Syjonu, obramowującymi rozdz. 60; pojawienie się w tym zakończeniu tematu ludu Jerozolimy, który nie pojawia się we wcześniejszych wierszach; świadomość odwlekania się spełnienia Bożych obietnic w 60,22b. ${ }^{234}$ Związki z Iz 62 są jeszcze bardziej skomplikowane. Nawiązuje on wyraźnie do rozdz. 60, gdyż od 62,2 adresatem jest ponownie Jerozolima/Syjon, przy czym w rozdz. 60-61 pojawia się jedynie nazwa

${ }^{232}$ Tak W. L a u, Schriftgelehrte Prophetie in Jes 56-66, s. 66.

${ }^{233}$ Co do początku jednostki tekstowej z 61,1 istnieje zasadnicza zgoda wielu badaczy, np. C. W e s t e r m a n n, Das Buch Jesaja: Kapitel 40-66, s. 293; J.L. K o o l e, Isaiah III, t. 3: Isaiah 56-66, s. 266.

${ }^{234}$ Zob. K. K o e n e n, Ethik und Eschatologie im Tritojesajabuch, s. 142-152, dla którego dodatkami są 60,19-20.21.22a.22b; O.-H. S t e c k, Der Grundtext in Jesaja 60 und sein Aufbau. Studien zu Tritojesaja, s. 51-53, który 60,17-22 uważa za wtórne. 
„Syjon” (i to tylko dwa razy: 60,14; 61,3). Jest to obietnica nadchodzącego zbawienia dla Jerozolimy. O ile 62,6 zdaje się być słowem Bożym, to 62,1 głos zabiera ,ja”, mówiąc o Syjonie (w 3. os.), przez co przypomina rozdz. $61 .{ }^{235}$ Wprawdzie 62,1 zdaje się łączyć z 61,1-3.10 prorockie ,ja”, to jednak wiersz ten jest ściśle związany nie tylko z 62,2-3 (zob. kluczowe pojęcia „sprawiedliwość” i „chwała”), ale i z kolejnymi (nowe imię podaje dopiero w.4; niemilknięcie wraz ze wskazaniem „dopóki” powtarza się w w.6-7). Nie próbując tutaj rozstrzygnąć szczegółów dotyczących pochodzenia i złożoności korpusu Iz 60-62, można jednak stwierdzić, że stanowią pewnego rodzaju całość, ale całość redakcyjną. Najbardziej charakterystyczną odmiennością rozdz. 61 jest jego niezaadresowanie do Syjonu. Jest wprawdzie w nim mowa o odbudowie ruin, ale bezpośrednio kwestia murów się nie pojawia (inaczej niż w 60,10-11 czy 62,6 $6^{236}$ ). Mimo podobieństw i wspólnych wątków rozdz. 61 jest jednak odrębną całością. ${ }^{237}$

Można mieć wątpliwości, c z y rozdz. 61 jest jedną pe r y k o p ą. Wątpliwości dotyczą w pierwszej kolejności w.1-3, a także w.10-11, zwłaszcza że w.10 (z w.11 lub bez niego) postrzegany bywa jako pierwotnie odrębny fragment. ${ }^{238}$ Wiersze $10-11$ nie tylko 1 . os., ale również leksykalnie i użytymi obrazami, nawiązują do w.3ay-b, ${ }^{239}$

${ }^{235}$ Zaskakuje, że L. R u s z k o w s k i, Volk und Gemeinde im Wandel, s. 15-27, w ogóle pomija różnice wewnątrz rozdz. 60-62.

${ }^{236}$ W którym niekoniecznie ma się na uwadze już odbudowane mury, zob. O. H. S t e c k, Zu jüngsten Untersuchungen von Jes 60-62, s. 128 i J. G o 1 d i n g a y, A Critical and Exegetical Commentary on Isaiah 56-66, s. 338-339.

${ }^{237}$ Tak też W. L a u, Schriftgelehrte Prophetie in Jes 56-66, s. 89.

${ }^{238}$ Już K. M a r t i, Das Buch Jesaja, Kurzer Hand-Commentar zum Alten Testament X, Tübingen i in. 1990, s. 387-388, których sądził, że w.10 miał stać po 62,12; B. D u h m, Das Buch Jesaja, s. 425-426, biorący wiersz za dodatek, który jednak może pochodzić od Tritoizajasza; C. W e s t e r m a n n, Das Buch Jesaja: Kapitel 40-66, s. 295, który przestawiał kolejność w.10 i 11, co jednak zmuszałoby do odpowiedzi na pytanie, jak mogło dojść do tak ,nieuzasadnionego” przestawienia tych wierszy (trudno wyobrazić sobie taki błąd kopisty, a jeszcze trudniej świadomą korektę); W. L a u, Schriftgelehrte Prophetie in Jes 56-66, s. 86-87.

${ }^{239}$ J.L. K o o 1 e, Isaiah III, t. 3: Isaiah 56-66, s. 266, twierdzi, że tworzą inlusio, co miałoby przemawiać za tym, iż w.10-11 zamykają jednostkę tekstową. 
tak że w.1-3 i 10-11 tworzą obramowanie dla w.4-9. Choć w.1-3 i 10-11 ze sobą są mocno terminologicznie związane, to jednak związki takie z resztą rozdziału są stosunkowo skąpe i ograniczają się do rzeczownika ארץ, który jednak inaczej niż w w.7 użyty został w ogólnym sensie w obrazie ziemi, wypuszczającej pędy; powszechnego czasownika (w odmiennych formach w w.2.3.6) oraz bardziej znaczących: sformułowania „Bóg nasz” (w.2 i 6) i powracającej w w.11 sprawy narodów (por. w.5-6.9). Gdyby słownictwo byłoby rozstrzygającym argumentem, to mogłoby prowadzić do podziału rozdziału na dalsze drobne jednostki tekstowe. Dotyczyłoby to w szczególności w.4, który terminologicznie poza עוֹל , aży ale uż nieco innym sensie, nic nie łączy z resztą rozdziału. W.1-3 zdają się mieć na uwadze położenie wygnańców i rozproszonego po świecie ludu Bożego, którzy są uciskani i więzieni, zniechęceni i pogrążeni w żałobie (po Syjonie) i którym odmianę losu ogłasza sługa-prorok. Z kolei w.4-9 dotyczą sytuacji w kraju Izraela, Jerozolimy i jej bliższej czy dalszej okolicy. Jerozolima i miasta opisane zostały jako ruiny (w.4), które mają być odbudowane, wysiedleni mają dopiero otrzymać ziemię (w.11), na której pracować będą obcy (w.5). Obietnica obejmuje odnowę ludu (w.9), zawarcie z nim przymierza (w.8b), czerpanie z bogactwa narodów (w.6b) jako Boży kapłani (w.6a). Choć perspektywa w.1-3 i 4-9 wydaje się odmienna, to łączy jeszcze całkowita mizeria na wygnaniu czy w kraju, nie mówiąc już o tym, że w.7 odnosi do sytuacji wygnańców.

Z tym wiąże się też pytanie o in te g ralność litera cką tego rozdziału, do postawienia którego mogą skłaniać zmiany osób gramatycznych (mowa w 1. os. w w.1 i 10 wraz z określeniem ,nasz Bóg" w w.2 i 6; adresat w 2. os. pl. w w.5-6, podczas gdy w pozostałych w.1-4.7[kor.]-9 odbiorcy obietnicy pojawiają się w 3. os. pl.) czy też fakt, że można w nim wyróżnić kilka mniej lub bardziej ze sobą powiązanych części (zob. powyższe uwagi do budowy całości). Dlatego trudno się dziwić, że niektórzy badacze wysuwali hipotezy, że Iz 61 nie jest literacko jednolity.

K. Koenen (Ethik und Eschatologie im Tritojesajabuch, s. 105-122) podejrzewa, że w.5-6 mogą stanowić uzupełnienie (Fortschreibung) 
w.4, a w.7-9 Fortschreibung w.1-4.5-6 (por. תַ czy 2. os. na początku w.7 [TM]), dla których nie można wykluczać ani Tritoizajaszowego, ani redakcyjnego pochodzenia. Zaś bez wątpienia redakcyjne są w.10-11, które mają być hymnem Syjonu w reakcji na poprzedzające obietnice zbawienia. Został on połączony się z poprzedzającymi wierszami za pomocą słów kluczowych. Ich wtórność redakcyjną uzasadnił wyłącznie leksykalnie oraz nieco innym użyciem obrazu pana i pani młodej w Iz 62.

Podobnie W. Lau (Schriftgelehrte Prophetie in Jes 56-66, s. 80) nie wyklucza, że w.5-6 są wtórne, ale pasują jednocześnie do Tritoizajaszowego kontekstu.

Natomiast O.-H. Steck (Der Rachtetag in Jesaja 61,2, s. 107, przyp. 3 i 4) wyklucza operacje literackokrytyczne w rozdz. 61, z wyjątkiem podejrzanego wyrażenia „opłakujących Syjon” (w.3) ${ }^{240}$ i wtórnego „dnia zemsty” (w.2; tamże, 116-118), które w ramach redakcji ogólno-Izjaszowej (Iz 34,8 miał wpływ na 59,17 i przede wszystkich 63,1-6) zastąpił pierwotne יום ישואיטה, jako wiersz ten opiera się na 49,8.

S. Labouvie (Gottesknecht und neuer David, s. 49-59) zaproponowała daleko idące zróżnicowanie literackokrytyczne (warstwa podstawowa i dwa opracowania redakcyjne). Dodatkami miałyby być: w.2a (dublet לקר? - por. w.1b; pierwsza część ma być interpretacją דירוֹר , a druga wprowadzać motyw prorockiego zwiastowania sądu);

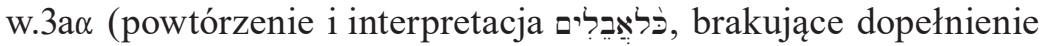
w acc.); w.5-6 i 7a $\alpha$ (TM; pojawienie się 2. os. pl., o ile w.3 miał mówić o przywróceniu wcześniejszej sytuacji, to domniemany dodatek o otrzymaniu majątku, władzy i chwały od narodów); w.7aß-b (jako

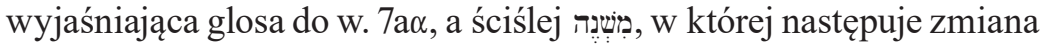
liczby gramatycznej); w.8-9 (z powodu mowy JHWH, powtórzeń słów z wcześniejszych wierszy, zaś przymierze ma być nawiązaniem do tradycji Abrahama). Trzeba stwierdzić, że postulowane dublety ograniczają się do pojedynczych słów (czyżby autor nie mógłby użyć dwa razy tych samych słów?). Zupełnie niejasne jest, na jakiej podstawie autorka oddziela pierwotną wypowiedź od jej interpretacji (zob.

${ }^{240}$ Tak też już dużo wcześniej B. D u h m, Das Buch Jesaja, s. 424-425. 
postulaty dotyczące w.2a.5-7a $\alpha .8-9$ ). Poza od dawna dostrzeganymi trudnościami z osobami gramatycznymi oraz konstrukcją w.3aa studium nie dodaje żadnej nowej uzasadnionej obserwacji.

Ostrożniej do sprawy podchodzi A. Span (Die Stadtfrau Zion im Zentrum der Welt, s. 254), uznając za redakcyjne uzupełnienie w.10-11, bo posłużono się w nich językiem typowym dla psalmów.

Mimo tego, że można znaleźć punkty zaczepienia do stosowania krytyki literackiej, to jednak nie da się uzasadnić wystraczająco wtórności poszczególnych wierszy. Użycie w w.5-6 2 os. pl. nie uzasadnia jeszcze ich wtórności, tym bardziej że jednocześnie dostrzega się ich dopasowanie do (Tritoizajaszowego) kontekstu. Za wtórnością w.7-9 poza problematycznym suf. w pierwszej części wiersza zupełnie nic nie przemawia. Podobnie ma się sprawa $z$ całkowicie hipotetycznym postulatem, jakoby zależność w. 2 od 49,8 była tak mocna, że pierwotnie musiał stać tam „dzień zbawienia”, zmieniony pod wpływem Iz 34,7. Pojawiające się więcej niż jeden raz słowa nie można automatycznie zaliczać do dubletów, bez rozważenia ich funkcji kompozycyjnej i znaczenia poszczególnych zdań. Natomiast nie można wykluczyć zakłócenia tekstu jedynie na początku w.3 (zob. powyższa uwaga do tłumaczenia). Tylko to wyrażenie wiąże cały rozdział 61 jednoznacznie z Syjonem (można by się tego domyślać z w.4; por. też „kapłani” w w.6), a tym samym z Iz 60 i 62 . Jeśli jest być wtórne, to samodzielność Iz 61 staje się jeszcze wyraźniejsza. Można by sobie również wyobrazić, że w.10-11 są redakcyjnie stworzonym, bazującym na w.1-3, końcowy obramowaniem. Dodatkowym argumentem mogłoby być, że o ile w w.2 mowa jest o „naszym Bogu”, to w w.10 o „moim Bogu”. Ponieważ takiej hipotezy nie da się lepiej ugruntować (rzeczywistymi dubletami, sprzecznością itp.), to wydaje się problematyczne postulowanie redakcyjnego pochodzenia w.1011. Nie inaczej trzeba ocenić w.4, bo nowy wątek tematyczny, ale nie sprzeczny z kontekstem, nie powinien być podstawą ingerencji literackokrytycznych. 
Iz 61 nawiązuje do tekstów Deuteroizajaszowych oraz psalmów, choć z różną intensywnością. ${ }^{241}$ Najwyraźniej ma to miejsce w w.1, którego tłem jest powołanie sługi z 42,1-4. Istnieje też wiele związków leksykalnych z 40,6.9; 49,9; 52,7, a także w odniesieniu do adresatów z 49,25-26; 52,2. Ponadto w.2-3 wykorzystują czy mogą wykorzystywać motywy z 49,8 (czas Bożej przychylności) oraz motyw pocieszania $(40,1-2 ; 49,13 ; 51,12 ; 52,9$ czy 51,3.19), pieśni pochwalnej (Iz 42,8.10.12; 43,21 i 48,9; zob. też 61,11) i wychwalania (פאר hitp. Iz 44,23; 49,3). Na uwagę zasługują ponadto paralele do Ps 45,8. Z pozostałych wierszy w szczególnych sposób powiązane z Iz 40-55 są: w.4 ( בנה - por. 44,26.28; 45,13; חרש - 42,10; 43,19; ruiny - 44,26; 49,19; 51,3; 52; spustoszenie - 49,8.19; miasta-judzkie w 40,9; 44,26; „,ruiny wieczne" - 49,13) oraz 8 (,ja jestem JHWH” - 43,3.11.15;

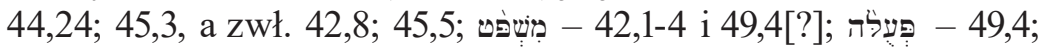
- 42,6; 49,8, a także 45,10 i 55,3). W przypadku w.9 na Iz 44,3

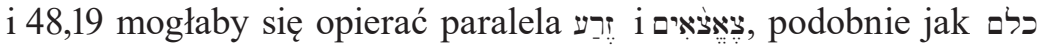
בוש w w.7 na 54,3-4 (są one zbyt rozpowszechnione w Starym Testamencie, by móc wyciągać dalej idące wnioski). Do tego dochodzi jeszcze charakterystyczne wyrażenie שִׁמְחָת עוֹלום z w.7, które pojawia się w Iz $35,10=51,11$, co jeszcze nie musi świadczyć o późnym pochodzeniu wiersza, gdyż redaktor(zy) mógł(mogli) je zaczerpnąć właśnie z 61,7. Za tym przemawia już fakt, że 35,10 kombinuje to wyrażenie z wyobrażeniami z 61,3. ${ }^{242}$ Metaforyka wypuszczającej pędy sprawiedliwości w w.11 opiera się prawdopodobnie na Iz 45,8. Rozkład tych nawiązań i paraleli mógłby prowadzić do hipotezy

${ }^{241}$ Do szczegółów zob. powyższy komentarz. Już B. D u h m, Das Buch Jesaja, s. 424, nie miał wątpliwości, że treść obietnic naznaczony jest przez Deuteroizajasza i Pieśni o słudze Pana.

${ }^{242} \mathrm{Na}$ co uwagę zwraca H.-J. He r m i s s o n, Deuterojesaja, cz. 3: Jesaja 49,14 55,13, s. 285, który sądzi ponadto, że Iz 51,11 opiera się na Iz 35,10. Zastanawia, że pojawienie się „radości wiecznej” tylko te trzy razy w całej Biblii Hebrajskiej nie zostało odnotowane w ramach pytania o jego pochodzenie czy powiązane z 61,7 ani tamże, s. 283-285 (w komentarzu do 51,11), ani w H. W i 1 d b e r g e r, Jesaja, cz. 3: Jesaja 28-39. Das Buch, der Prophet und seine Botschaft, BK X/3, Neukirchen-Vluyn 1982, s. 1366 (w komentarzu do 35,10). 
o odrębności w.1-3.(10-)11 oraz w.4 (wyjaśniałoby, dlaczego nowy podmiot znajduje się dopiero w w.5), ale już w przypadku w.8 trudno byłoby wyciągnąć tego rodzaju wnioski (a także próbować dowieść, że do Iz 61 nawiązywali późniejsi redaktorzy Dtiz).

Historia powstania Iz 40-55 w badaniach jest bardzo różnie oceniana. ${ }^{243} \mathrm{~W}$ każdym razie powstanie tych rozdziałów przez R.G. Kratza było datowane w przypadku tzw. Ebed-Israel-Schicht na pierwszą połowę $\mathrm{V}$ w. p.n.e. i przed Iz $60-61,{ }^{244}$ a przez H.-J. Hermissona na wczesnopowygnaniowy okres (najpóźniejsze z Naherwartungsschicht), krótko po 540 r. p.n.e., ${ }^{245}$ przy czym to teksty Tritoizajaszowe są od niej zależne, a nie odwrotnie. ${ }^{246}$

Podsumowując kwestię złożoności literackiej, można stwierdzić, że:

- Iz 61 może być kompozycją składającą się z mniej lub bardziej samodzielnych jednostek w.1-3/4/5-6/7-9/10-11, z których każda miałaby swój własny akcent tematyczny (co w najmniejszym stopniu odnosi się do w.10-11). Jednak część z nich byłaby wyraźnie fragmentaryczna, co w szczególności dotyczyłoby w.4 czy w.5-6 (temat narodów wiąże je z w.9, ale przeciwko

${ }^{243}$ By przywołać kilka najważniejszych przykładów R.P. M e r e n d i n o, Der Erste und der Letzte: Eine Untersuchung von Jes 40-48, VT.S 31, Leiden 1981 (i jego dalsze artykuły ukazujące się w kolejnych latach); H.-J. He r m is s o n, Einheit und Komplexität Deuterojesajas: Probleme der Redaktionsgeschichte von Jes 40-55, w: J. V e r m e y l e n (red.), The Book of Isaiah / Le livre d'Isaĩe, Bibliotheca Ephemeridum theologicarum Lovaniensium 81, Leuven 1989, s. $287-$ -312 (oraz jego komentarze; podsumowanie w H.-J. H e r m i s s o n, Deuterojesaja, cz. 3: Jesaja 49,14 - 55,13, s. 655-760); R.G. K r a t z, Kyros im Deuterojesaja-Buch; J. va n O o r s chot, Von Babel zum Zion; J. S l a w i k, Historia redakcji pierwszej części Księgi Deuteroizajaza (Iz 40-48).

${ }^{244}$ R.G. K r a t z, Kyros im Deuterojesaja-Buch, s. 215 i przyp. 683, który, łącząc Iz 60 i 61, musi je datować po dobudowie świątyni (por. Iz 60,7), a przed odbudową murów (por. Iz 60,10).

${ }^{245}$ H.-J. H e r m i s s o n, Einheit und Komplexität Deuterojesajas, s. 310; t e n ż e, Deuterojesaja, cz. 3: Jesaja 49,14 - 55,13, s. 733, przy czym zasadniczo możliwe jest jedynie relatywne datowanie tej warstwy.

${ }^{246}$ Tamże, s. 733-734. 
oderwaniu w.9 od w.7-8 może przemawiać powiązanie kraju i potomstwa w tradycjach o patriarchach - por. Rdz 28,13-14). ${ }^{247}$

- Wiersze 1-3 i 10-11 mogły od razu stanowić całość i być samodzielne. Mimo że bez w.1-3 przynajmniej w.4 wisiałby trochę w powietrzu, to pozycja tych wierszy na początku i końcu perykopy sugeruje ich kompozycyjne (choć niekonieczne redakcyjne) rozmieszczenie. Wiele wskazuje na to, że wiersze te stanowiły wpierw odrębną jednostkę tekstową, ale nawet w tym przypadku lepiej odczytywać rozdz. 61 jako jedną całość. Nie da się wykluczyć, że ,abym dał opłakującym Syjon” z w.3 mogą być wyjaśniającą glosą i/lub dodatkiem wiążącym te wiersze $\mathrm{z}$ rozdziałem $60 \mathrm{i}$ być może 62 .

- Powiązanie z Iz 60 i 62 prawdopodobnie nie jest pierwotne, co dotyczy również utrzymanego w 1. os. 62,1, który nie tylko wprost mówi o Jerozolimie, ale zakłada oczekiwanie na spełnienie Bożych obietnic wobec Jerozolimy (nie mówiąc już o tym, że 62,1 jest mocno powiązany z kolejnymi wierszami aż po wyraźnie rzeczowo i językowo z nim związany 61,7).

D a tow a n i e rozdz. 61 jest niepewne. Wiersze 1-3 opisują położenie zniechęconych i więzionych wygnańców i rozproszonego po świecie ludu Bożego, zaś w.4-9 są obietnicą dla kraju Izraela, Jerozolimy i jej bliższej czy dalszej okolicy, które leżą jeszcze ruinach, a wysiedleni mają dopiero otrzymać ziemię. Datowanie utrudnia fakt, że niestety nic pewniejszego nie wiemy o tym, jak toczyły się losy społeczności powygnaniowej. Wezwania do odbudowy świątyni, co miało przypuszczalnie miejsce w latach 520-515 p.n.e. (za Dariusza - zob. Ezd 6), z Ag 1, zakładają, że wprawdzie mieszkańcy Jerozolimy są biedni, ale jakaś odbudowa miała już miejsce $(1,4)$. Potrzeba odtworzenia życia na wszystkich płaszczyznach, czyli uwolnienie, odbudowa, przydzielenie ziemi (na której mają pracować cudzoziemcy), sugerowałoby powstanie Iz $61 \mathrm{w}$ bardzo wczesnych latach powygnaniowych. W tym kontekście zastanawia, że odbudowa świątyni nie jest w ogóle wzmiankowana (obecny jest jednak motyw

${ }^{247}$ Zob. powyżej. 
kapłaństwa), tak że powstaje pytanie, czy odbudowa świątyni była jeszcze stosunkowo odległą kwestią, czy też świątynia już istniała (co znajduje odzwierciedlenie np. w 60,7.13; 62,9). ${ }^{248}$ Podobnie mają się sprawy w przypadku Iz 40-55, gdzie świątynię wspomina jedynie wtórny 44,28b. ${ }^{249}$ Jednak z milczenia na jakieś temat trudno wysnuwać dalej idące wnioski. ${ }^{250}$ Bliskość koncepcyjna $z$ takimi tekstami jak dwie pierwsze Pieśni o słudze JHWH i innymi fragmentami z tych rozdziałów wskazuje na bliskość czasową, tak że przenoszenie powstania Iz 61 na odległy od umownego końca wygnania w 539 r. p.n.e. okres nie wydaje się sensowne, tj. poza drugą połowę VI w. p.n.e. ${ }^{251}$

\section{Wnioski}

Wprawdzie można by próbować odtworzyć domniemaną historię powstania Iz 61, na którą składałyby się drobne fragmenty w.5-6/7-9, połączone z w.1-3, które wraz z w.10-11 stworzyły obramowanie

${ }^{248}$ Zob. O.-H. S t e c k, Jesaja 60,13 - Bauholz oder Tempelgarten, w: t e n ż e, Studien zu Tritojesaja, s. 101-105; t e n ż e, Der Rachtetag in Jesaja 61,2, s. 116 (do tego też K. K o e n e n, Heil den Gerechten - Unheil den Sündern. Ein Beitrag zur Theologie der Prophetenbücher, BZAW 229, Berlin i in. 1994, s. 69-70, przyp. 2). Jeśli łączyć rozdz. $60+62$ i $61 \mathrm{w}$ jedną kompozycję, to musiała ona powstać po odbudowie świątyni. W. L a u, Schriftgelehrte Prophetie in Jes 56-66, s. 117, mówi o pierwszej połowie $\mathrm{V}$ w. p.n.e.

${ }^{249}$ Powszechnie uważany za późniejsze uzupełnienie (z czasów, gdy kwestia odbudowy świątyni nabrała znaczenia, tj. ok. 520 r. p.n.e.); K. E 11 i g e r, Deuterojesaja, s. 457 (dodatek post eventum); R.G. K r a t z, Kyros im Deuterojesaja-Buch, s. 88-89 (wczesnokronikarski); J. S l a w i k, Historia redakcji pierwszej części Księgi Deuteroizajaza (Iz 40-48), s. 111-112; H.-J. H e r m i s s o n, Deuterojesaja, cz.3: Jesaja 49,14 - 55,13, s. 734 (bez próby datowania).

${ }^{250}$ Dodać można kolejne pytanie o to, czy nawiązanie do postaci sługi JHWH z Pieśni o słudze (i tekstów z nimi powiązanych) przy jednoczesnym pominięciu śmierci sługi (por. Iz 52,13-53,12), miałoby świadczyć o powstaniu przed Iz 53.

${ }^{251}$ Zob. H.-W. J ü n g 1 i n g, Das Buch Jesaja, s. 445-447, powołując się na model M. Sweeneya, który przewiduje powstanie rozdz. 60-62 pod koniec VI w. (520-515 p.n.e.); podobnie K. K o e n e n, Ethik und Eschatologie im Tritojesajabuch, s. 215. Dla Dtiz opowiadam się raczej za datowaniem H.-J. H e r m i s s o n a, Deuterojesaja, cz.3: Jesaja 49,14 - 55,13, s. 731-737. 
całości, w którą włączono też w.4, a także stworzono jednoznaczne powiązanie z Iz 60 i 62, wskazując, że perspektywą jest powodzenie mieszkańców Syjonu (glosa „opłakujący Syjon”), to jednak cała taka rekonstrukcja bazowałaby na dość wątłych podstawach. Przede wszystkim ze względów pragmatycznych lepiej jest potraktować rozdział jako całość, stanowiącą przemyślaną kompozycję. Iz 61 jest ostatecznie produktem literackim, który mogły poprzedzać takie czy inne fragmenty (przede wszystkim w.1-3+10-11 czy w.[4.]5-9). Odbiorcami są przede wszystkim wygnańcy i rozproszenie Izraelici, którzy wracają i powrócą do Jerozolimy i miast judzkich oraz którym Bóg obiecuje restaurację i na nowo zorganizowane życia w dawnej ojczyźnie. Oni stanowią jądro ludu Bożego. Do ich dobrobytu przyczynią się także obcy (w.5-6), którzy w takiej czy innej formie uznają kapłański status ludu Syjonu. Ponieważ zależność od tradycji Deuteroizjaszowych i niektórych Psalmów jest wyraźna, to teza o uczonym w Piśmie profetyzmie (schriftgelehrte Prophetie), tj. literackiej aktywności typu prorockiego, która sięga po wcześniejsze przekazy, jawi się jako zasadniczo słuszna. ${ }^{252}$ Ale określenie to nie jest do końca precyzyjne, ${ }^{253}$ gdyż mamy do czynienia nie tylko z aktualizacją wykorzystanych tradycji, ale również z nowymi obietnicami (w.5-6) czy ujętymi w nowy sposób (np. odszkodowanie z w.7). Nie sposób wykluczyć ani potwierdzić, że w perykopę Iz 61 wkomponowane zostały jakieś krótkie wcześniejsze przekazy, z których pochodzą te obietnice. Tak czy inaczej w Iz 61,1-3.10(-11) do głosu dochodzi proro-

252 Jak głosi tytuł i główna teza W. L a u, Schriftgelehrte Prophetie in Jes 56-66, który jednak mówi jeszcze mówi o uczonym w Piśmie proroku - osobowości prorockiej; zob. też O.-H. S t e c k, Die redaktionsgeschichtliche Hypothese zu Tritojesaja im Umriß, s. 44.

${ }^{253}$ Zastrzeżenie zgłosił również L. R u s z k ow s k i, Volk und Gemeinde im Wandel, s. 17-18, który, bazując na koncepcji kognitywnego dysonansu wynikającego z niewypełnienia się obietnic Deuteroizajasza, odnajduje dwie możliwości radzenia sobie z nim: 1) przez nowy wykład obietnic, w którym ich spełnienie staje się łatwiejsze; 2) przez dodanie słów, które świadczą o tym, że proroctwa jednak się spełniają. Schriftgelehrte Prophetie miałoby dotyczyć tylko pierwszego z tych dwóch sposobów. 
ckie ,ja”, a więc mogłoby się wydawać, że u podstaw tych przekazów mamy do czynienia z prorokiem. Hipotezie takiej zdaje się jednak przeczyć stylizacja ,ja” z tych wierszy na sługę-proroka z Iz 40-55 (przede wszystkim dwóch pierwszych Pieśni do słudze JHWH), co każe raczej myśleć o tradentach tradycji Deuteroizajaszowych (O.H. Steck). Czy istniał zatem prorok Tritoizajasz? Wiele wskazuje na to, że trzeba udzielić negatywnej odpowiedzi. Istniał czy istnieli natomiast tradent lub tradenci (autorzy-redaktorzy), którzy uaktualniali przekazy Deuteroizajaszowe, nie tylko je redagując, ale również tworząc oparte na nich własne kompozycje. Ponadto chciał(chcieli) przekazać nowe obietnice. Swoją misję postrzegał(li) jako na wskroś prorocką, a jednocześnie jako wypełnianie zadania sługi JHWH, z którym się identyfikował(li). Ważność zachowywały obietnice JHWH uwolnienia i odrodzenia się ludu Bożego, restauracji kraju, w centrum którego leżał Syjon. Obietnice te wyraźniejsze kontury uzyskują w Iz 60 i 62. Do tego dochodzi uznanie ze strony narodów i ich podległość ludowi Bożemu, który ma jako całość pełnić funkcję kapłanów JHWH.

Czy kompozycja Iz 61 byłaby zrozumiała odczytana samodzielnie, a nie jako redakcyjne opracowanie Iz $40-55 ?^{254}$ Dla nas dzisiaj interpretacja Iz 61 (i całego Iz 56-66) bez znajomości Dtiz byłaby z pewnością bardzo utrudniona. Zaś o historycznych odbiorcach w drugiej połowie w VI w. p.n.e. nic nie da się powiedzieć. Choć pytania tego rodzaju są ciekawe, to z powodu skromności źródeł muszą siłą rzeczy pozostać bez odpowiedzi.

\section{$* * *$}

Egzegeza Iz 61 pokazała, że rozdział ten jest odrębną kompozycją, która składa się z ram w.1-3.10-11 i części środkowej w.4-9. Części te nie musiały od samego początku być jednym fragmentem. Podejrzany literackokrytycznie jest w.3aa, który obecnie wiąże Iz 61 z sąsiednimi

${ }^{254}$ O.-H. S t e c k, Die redaktionsgeschichtliche Hypothese zu Tritojesaja im Umriß, s. 12, uważa, że od samego początku Iz 60-61* był kontynuacją Iz 49-55. 
rozdziałami 60 i 62. Jednak cała perykopę najlepiej jest interpretować jako jedną całość, w której głos zabiera prorockie ,ja” stylizowane na sługę proroka z Deuteroizajaszowych Pieśni o słudze JHWH. Za tym „ja” kryją się przypuszczalnie tradenci tradycji Deuteroizajaszowych uaktualniający jego obietnice i dodający nowe. W takim razie prorok Tritoizajasz, który miałby przypominać wcześniejszych proroków, przemawiających do ludu, nigdy nie istniał. Nie zmienia tego fakt, że tradenci ci uważali się za sługi JHWH i postrzegali swoją misję jako prorocką.

Jakub SLAWIK

Stowa kluczowe: Tritoizajasz; interpretacja Iz 61; krytyka literacka; historia redakcji; profetyzm uczony w Piśmie; pisemna posługa prorocka

Keywords: Tritoisaiah; interpretation of Is 61; literal criticism; redaction criticism; scribe prophecy; prophetical ministry in writing

\section{Exegesis of Isaiah 61: Redaction Criticism and a Question of the Identity of the Prophet called Trito-Isaiah}

Summary

Exegesis of Is 61 has shown that the chapter is a literal composition, which consists of two parts: a frame vv. 1-3+10-11 and a middle part vv. 4-9. The two framing sections, vv.1-3(10-11) could first have been a separate text. V. 3aa is possibly a secondary addition, which joins chapter 61 with chapters 60 and 62. But it is reasonable to read and interpret Is 61 as one unit, in which a prophetic „I" take the floor. The „I” poses as a servant known from Deutero-Isaiah's Songs of JHWH's Servant. But in this „I” we hear tradents who passed down and updated Deutero-Isaiah's tradition, and added new God's promises. The prophet Trito-Isaiah, who should be like the other prophets speaking to the people, never existed. However the tradents understood their mission as prophetical one. 